\title{
PERSUASIVE PROPAGANDA DURING THE 2015 ARGENTINE BALLOTAGE
}

\author{
Rafael Di Tella
}

Sebastian Galiani

Ernesto Schargrodsky

\section{LATIN AMERICAN AND THE CARIBBEAN ECONOMIC ASSOCIATION}

October 2019

The views expressed herein are those of the authors and do not necessarily reflect the views of the Latin American and the Caribbean Economic Association. Research published in this series may include views on policy, but LACEA takes no institutional policy positions.

LACEA working papers are circulated for discussion and comment purposes. Citation of such a paper should account for its provisional character. A revised version may be available directly from the author.

(C) 2019 by Rafael Di Tella, Sebastian Galiani and Ernesto Schargrodsky. All rights reserved. Short sections of text, not to exceed two paragraphs, may be quoted without explicit permission provided that full credit, including (C) notice, is given to the source. 
LACEA WORKING PAPER SERIES No. 0034 October 2019

Persuasive Propaganda during the 2015 Argentine Ballotage

Rafael Di Tella

Harvard Business School, CIfAR and NBER

rditella@hbs.edu

Sebastian Galiani

University of Maryland and NBER

galiani@econ.umd.edu

Ernesto Schargrodsky

UTDT and CONICET

eschargr@utdt.edu

\begin{abstract}
We study a propaganda campaign sponsored by the government against the main political challenger in the days preceding the 2015 Argentine runoff presidential election. Subjects in the treatment group watched an "ad" initially aired during soccer transmissions that was part of this campaign and were then asked about their political views. Relative to subjects in the control group, their declared preference for the challenger drops by 6.5 percentage points. We find no effects of the three types of defenses employed by the challenger (a positive message unrelated to the "ad", an answer to the accusations in the "ad", and a counter-attack). The propaganda effect is driven by women.
\end{abstract}

JEL Classification: D72, P48.

Keywords: Propaganda, Persuasion, Voting.

\title{
ACKNOWLEDGEMENTS AND FINANCIAL DISCLOSURE
}

We are grateful to consulting firm Wonder for data provision, to Lucia Freira and Martin Caruso Bloeck for excellent research assistance, and to Vincent Pons, Julio Rotemberg and participants at several seminars and conferences for helpful suggestions and discussions. None of the authors participated in the 2015 political campaign. Sebastian Galiani was Secretary of Economic Policy (deputy-minister) of the Treasury in the Macri administration during 2017-2018. 


\section{Introduction}

An important question in politics concerns the ability of politicians to affect voter preferences through propaganda. In advanced democracies, political campaigns have traditionally been constrained by norms and institutions; for example, by limiting the extent to which candidates can lie or make misleading statements about their competitors, or by restricting the financial influence of the State on media companies. Democratic institutions complement a free press, for example, ensuring competition so that people who do not want to consume political advertisement can avoid it. In poor countries these constraints are often absent, so Statesponsored propaganda is more frequent and presumed to be more effective. However, it is also possible that people used to living under these institutional settings are more aware of the possibility of media bias and hence more likely to discount its influence on their views. ${ }^{1}$ In this paper, we study one attempt to influence voter preferences during the weeks prior to the Argentine presidential ballotage of 2015, a setting characterized by widespread use of statesponsored propaganda. Of course, the "fake news" phenomenon and the success of populist candidates in rich countries suggest that learning about the effectiveness of propaganda efforts is relevant more broadly.

We exploit two main aspects of the use of the media by the 2003-2015 Kirchners' administrations: the likely awareness of potential bias by consumers and a significant difficulty in avoiding these messages. There was widespread understanding of the biased nature of the messages released by the media that were influenced by the government. Gradually since the beginning of the administration, media companies either owned by the State or by regime proxies, or those heavily dependent on government advertisement, biased reports in favor of the government, and attacked critics and opposition politicians. This use of the media was not done in a hidden way, but openly defended as legitimate by some journalists and members of the government, citing a pro-business bias in traditional media. In other words, the bias in the Statesponsored media was admitted and defended publicly by Kirchners' supporters. Moreover, the efforts of the government included influence over a growing number of media outlets, either directly through ownership (by the State or regime insiders), or indirectly through the discretional distribution of government subsidies. Mandatory broadcasts of President Cristina Kirchner through all the TV and radio networks in the country simultaneously were also frequent. This drastically limited the ability of consumers to exit and follow their natural tendency to read and watch like-minded outlets.

\footnotetext{
${ }^{1}$ For evidence that State ownership of the media is lower in richer or less autocratic countries, see Djankov et al. (2003). For theoretical work explaining how mass media can be used by interest groups to achieve political goals see Glaeser, (2005) and Besley and Prat, (2006). Gentzkow et al. (2015) show little evidence of incumbent party influence on the press in the US in the period 1869-1928, with the exception of the Reconstruction South. In contrast, for the Cold War period, Qian and Yanagizawa-Drott (2017) show that the US media increases the coverage of human rights abuses in countries that are not aligned with the US when they rotate into the UN (and reduces the coverage for aligned countries). Egorov et al. (2009) provide theory and evidence suggesting that a free media is less likely to emerge in resource-rich economies.
} 
A main component of the propaganda machine was Futbol para Todos (Soccer for All), a TV show which since 2009 broadcasted for free in open TV the main soccer matches of the country (the $1^{\text {st }}$ and $2^{\text {nd }}$ division, the Argentina Cup, and the national team), replacing the previous broadcasting of soccer games through paid cable TV. The show audience was considerable, as soccer is extremely popular in Argentina. Political ads were regularly aired at halftime together with first-half game highlights. Futbol para Todos enjoyed the monopoly of Argentine soccer TV transmission. In this way, propaganda messages reached voters regardless of their political inclination.

In particular, we study the period just prior to the 2015 Argentine presidential runoff between Nestor Kirchner's former vice-president, Daniel Scioli, of the incumbent Peronist party and the challenger, Mauricio Macri. The runoff was scheduled four weeks after the $1^{\text {st }}$ round presidential election of October $25^{\text {th }}$. According to the initial polls Macri was expected to obtain a comfortable victory, ${ }^{2}$ when the government's propaganda machine was set in full motion. Twelve days later Scioli had almost closed the gap, with Macri finally winning the presidency by only 2.68 percentage points. Our study uses data obtained by a public opinion and marketing firm during this period. Starting on November $11^{\text {th }}$ and for the following 9 days, a group of subjects that was regularly engaged online by this firm watched one of the key pieces of propaganda employed in the campaign. This was an ad first aired during halftime of a soccer game that defined the season championship which "explained" the similarities between the economic program of the Argentine military dictatorship of 1976-83 and that of Macri's. The ad presented old statements by Macri and members of his team, and it compared them with statements of Jose Alfredo Martinez de Hoz, the Minister of Economy of the dictatorship who remains wildly unpopular in Argentina to this day, claiming explicitly that Macri had a similar economic program to that of the dictatorship, and wanted to "adjust" and open the economy, lower government spending, and reduce export taxes to bring about a drastic wage adjustment. One of the excerpts was particularly out of context: a clip of a young businessman Macri before he had entered politics explaining to a journalist that "costs are too high, and wages are a source of costs." Subjects were then asked to answer a follow-up opinion survey including their $2^{\text {nd }}$ round vote intentions. A sub-group was also asked to watch one of three alternative responses to the government campaign (the "antidotes"): a set of positive Macri's policy proposals, a denial by Macri of the accusations made to him in the propaganda ad, and a counter-attack on Scioli. A control group watched a neutral video describing the electoral rules.

The data reveal several interesting patterns. First, watching the government's propaganda caused subjects to reduce their intention to vote for Macri in the coming runoff election by 6.5 percentage points. This is paired with an increase of 2 percentage points increase in the intention to vote for Scioli and a 4.5 percentage point increase in the group that is undecided. The decrease

\footnotetext{
${ }^{2}$ For example, a poll published on November $11^{\text {th }}$ in a main Argentine newspaper predicted a victory of Macri over Scioli by almost 10 percentage points (54.8\% vs. 45.2\%). See "Macri consolida su ventaja sobre Scioli en la recta final hacia el ballotage," La Nacion, November 11 ${ }^{\text {th }}, 2015$. The final outcome of the $2^{\text {nd }}$ round was $51.34 \%$ for Macri vs 48.66\% for Scioli (see https://www.electoral.gov.ar/pdf/escrutinio definitivo 2da vuelta.pdf). Interestingly, polls had underestimated Macri's share of votes in the first round.
} 
in Macri's intention to vote implies a persuasion rate of $11.2 \%$, which is in the mid-range of the persuasion rates reported in della Vigna and Gentzkow (2010). Second, we find no effect of the "antidotes," consistent with the conclusions drawn by Macri's electoral team (as described, for example, in Iglesias Illa, 2016). Third, the results are driven by women: whereas the estimated coefficient on the propaganda campaign in the men subsample is zero, the propaganda campaign reduces the women's preference for Macri by almost 12 percentage points. There is also some evidence that women, in contrast to men, believe the campaign's message: that Macri would lower wages. A potential explanation for the gender difference is that women are more sensitive to the social concerns raised by the propaganda campaign (for evidence consistent with this, see Edlund and Pande, 2002, Alesina and La Ferrara, 2005, and the review by Niederle, 2016).

Social scientists have been interested in propaganda at least since Lasswell (1927), although much of the early research often uncovered effects described as "minimal" (see, for example, Klapper, 1960). ${ }^{3}$ Later studies documented a correlation between measures of exposure to political advertising and voter preferences (e.g., Baum, 2002). An early paper to study the causal effect of political advertising is della Vigna and Kaplan (2007), who exploit the staggered availability of the Fox News channel on voting in the US. They find Fox availability in otherwise similar towns increased the Republican share of votes in the 2000 presidential election by half a percentage point. ${ }^{4}$ A related study by Gerber et al. (2011) provides experimental evidence on the effects of political advertising during a gubernatorial campaign in Texas in 2006. Exploiting the random assignment of the launch date and volume of television advertising to each experimental media market, they find strong but short-lived effects on voter preferences captured with a large daily tracking poll (see, also, Huber and Arceneaux, 2007). ${ }^{5}$

Studies of the effect of the media outside of the US uncover bigger effects and are closer in spirit to the setting we study given the weaker institutional conditions. ${ }^{6}$ For example,

\footnotetext{
${ }^{3}$ As described in Iyengar et al. (1982), "Four decades ago, spurred by the cancer of fascism abroad and the wide reach of radio at home, American social scientists inaugurated the study of what was expected to be the sinister workings of propaganda in a free society. What they found surprised them. Instead of a people easily led astray, they discovered a people that seemed quite immune to political persuasion. Later research on persuasion drove home the point repeatedly: propaganda reinforces the public's preferences; seldom does it alter them (e.g., Katz and Feldman, 1962; Patterson and McClure, 1976; Sears and Chaffee, 1979).”
}

4 There is a vast literature on negative political advertising. A standard conclusion is that "the research literature does not bear out the idea that negative campaigning is an effective means of winning votes" (Lau, et al., 2007). For a review of the evidence available on persuasion, see della Vigna and Gentzkow (2010). Ansolabehere, et al., 1999 uncovers large effects on turnout and shows how the use of recall measures of ad exposure collected in surveys can be problematic and lead to biased estimates of its effects. Some of the most fascinating work in political economy involves the effects of persuasion on beliefs during conflicts (see, Gentzkow and Shapiro, 2004; Adena et al., 2015; Yanagizawa-Drott, 2014; Paluck, 2009; and della Vigna et al., 2014).

${ }^{5}$ Studies on political canvassing have found strong effects on voter turnout (see, for example Green and Gerber, 2015). A recent paper by Pons (2018) studies door-to-door canvassing in the 2012 French presidential election and finds substantial and persistent effects on voting.

${ }^{6}$ For a review of the political economy of mass media, see Prat and Stromberg (2013). Even absent differences in the quality of institutions, there appear to be interesting idiosyncratic variations. For example, Da Silveira and de Mello (2011) exploit the fact that during the second round of Brazilian gubernatorial elections, TV time is split 
Enikolopov, Petrova and Zhuravskaya (2011) study the government-controlled media market in Russia. They show how access to the one independent TV station was largely idiosyncratic conditional on observables and correlated with a decrease in the vote of the government party of almost 9 percentage points and a decrease in turnout of under 4 points. We see our paper as directly complementing their study, both because of the institutional setting, and because it uncovers a central role for consumers actively switching to watch alternative shows.

Our paper is also connected to papers focused on events studying misleading statements, or where consumers are actively trying to avoid propaganda. One example of the former is Di Tella, Galiani and Schargrodsky (2012) which studies false statements during the Kirchner's propaganda campaign prior to the nationalization of the water services in a setting that allows to contrast the effects on public opinion of political propaganda vs. real investments. Surprisingly, we find that groups that had objectively gained access to water following the privatization and subsequently enjoyed large welfare gains, were only marginally less likely to believe Nestor Kirchner's false claims that there had been no investment during privatization. In agreement with our new results, that paper found little effects of the firm's defense against these accusations. An example of the latter is Durante and Knight (2012), who provide a clean demonstration of how the consumption of the media changes with the perception of partisan bias. Using data for Italy under Silvio Berlusconi, they show that when news content on public television shifted to the right, right-leaning viewers increased their propensity to watch public channels, while left-leaning viewers reacted by switching to another channel controlled by the left. Importantly, this behavioral response did not fully offset the changes in public news content to the right. See also Knight and Tribin (2019a, 2019b), who show how Hugo Chavez's propaganda efforts generated different changes in audience across channels depending on the viewers' ideological inclination and on the availability of a remaining independent television channel.

Finally, our study is connected to a recent paper by Galasso and Nannicini (2016), which studies the differential reaction to political advertising across genders. They estimate a differential response of male and female voters to propaganda messages during two mayoral campaigns in Italy. As in our study, they find sharp gender differences. There are, however, several differences with our setting, including that they have variation in the gender of the candidate going negative. ${ }^{7}$

Section 2 describes State-sponsored propaganda during the three Kirchners' administrations. Section 3 describes our data and empirical strategy. Section 4 reports our main results of the effect of propaganda on voter preferences, as well as the effects of the "antidotes"

equally between first-round winner and runner-up. Using differences between rounds as a source of variation, they find a large causal effect of TV advertising on electoral outcomes.

${ }^{7}$ One of the episodes they study involves a female incumbent who "violently attacks" the male challenger, accusing him of communist ties in his youth. They find that males lean more toward the (female) sender of the negative attack, and females align with the (male) candidate targeted by the attack. 
employed by Macri's campaign. Section 5 presents heterogeneous effects and a robustness analysis. Section 6 concludes.

\section{Politics, Media and the 2015 Propaganda Campaign}

The episode we study took place in November 2015, at the end of twelve years of three Kirchner presidencies. Nestor Kirchner became president of Argentina in 2003 as the country was coming out of the deepest recession in its history. His wife Cristina Fernández de Kirchner succeeded him for the 2007-2011 and 2011-2015 periods. There are several features of Argentina's media landscape under the Kirchners that are particularly important for our study. Initially, their relationship with the media was good, and the government allowed a large merger of the cable industry in December 2007 that greatly benefited Clarin, the main media company. Soon, a bitter conflict emerged, and "Clarin lies" became the slogan of an intense government campaign that eventually led to the passing of a media law in October 2009 aiming to curtail the market power of existing media firms. Sponsored by the Kirchner government and replacing a law passed by the military dictatorship in 1980, the new media law was bitterly opposed by the main media companies.

The government directly controlled a few media outlets that were State-owned. It indirectly came to control several private outlets through regime insiders (although some of them did not have previous experience in the media industry). Moreover, the Kirchner government obtained favorable coverage from many outlets, regardless of their ideology, through a system of transfers under the disguise of "public advertising" (see Di Tella and Franceschelli, 2011; and Gervasoni and Tagina, 2019). ${ }^{8}$ The most extreme estimates put the fraction of controlled audiovisual outlets at $80 \%,{ }^{9}$ although their market share was certainly lower as some large media companies (like Clarin and La Nacion) remained independent and maintained a significant share of the audience. Journalists employed by media companies heavily dependent on government transfers regularly biased reports in favor of the government, and attacked critics and opposition politicians. Some of these attacks were carried out by the Kirchners themselves, against public figures (e.g., economists, journalists), firms (e.g., Shell, Suez) and members of the opposition (including Mauricio Macri), in many occasions mandatorily using all the TV and radio networks in the country ("cadena nacional'). The bias in the State sponsored media was explicitly defended by members of the government as a legitimate defense of "the people" against lobbying and pressure by interest groups, while the conflict over the new media law was labeled "the mother

\footnotetext{
${ }^{8}$ Also see http://blogdelmedio.com/shots/mapa-de-medios-oficialistas-aliados-al-gobierno-kirchneristaargentina-2013/, and https://www.lanacion.com.ar/1841286-pauta-oficial-2009-2015-todos-los-nombres-y-losmontos-cobrados.

${ }^{9}$ See, for example, https://www.abc.es/internacional/20121209/abci-argentina-entrevista-clarin201212081725.html.
} 
of all battles." Some of the media messages used by the government contained lies and/or misleading statements about its critics. One example is the Kirchners' propaganda campaign prior to the nationalization of the water services documented in Di Tella, Galiani and Schargrodsky (2012). These attacks were frequently denounced in the remaining independent media, and victims often attempted to limit them legally, but lies and wild inaccuracies continued to be used by the government's propaganda machine at crucial electoral moments. ${ }^{11}$ This suggests there was widespread understanding of the biased nature of the messages released by an industry that was deeply influenced by the government.

An important component of the use of State-sponsored media for political purposes was Cristina Kirchner's nationalization of the transmission of soccer matches in August 2009, eliminating pay-per-view fees under a TV show called Soccer for All, or, in Spanish, Futbol para Todos. The agreement of the government with the soccer federation covered soccer matches of the first and second division, Argentina Cup, and the national team. Games were broadcasted on public TV and made available for free to private open TV and cable networks with the stated purpose that "none of the more than 40 million Argentines be excluded". The Facebook page of Futbol para Todos had 1.8 million followers, besides an exclusive app and a YouTube channel. The audience was considerable, with an average of 10 rating points for an average match, with more than twice that amount for matches involving the two most popular teams, Boca Juniors and Racing Club (see Grinberg, 2015). ${ }^{12}$ Initially, the announced intention was to guarantee the contracted income to the soccer federation, and to cover transmission fees with private ads. However, the vast majority of the advertising soon became State-sponsored "official ads." 13 This allowed the government to insert political messages during half-time together with the highlights of the first half of the match, so they received considerable attention. Since soccer is very popular, and there were many matches each week strategically scheduled, the program ensured that these messages reached most socioeconomic and regional groups.

\footnotetext{
${ }^{10}$ See, for example, the interview of one of its main sponsors in "La Madre de Todas las Batallas es una Nueva Ley de Radiodifusion", La Nacion, April 13, 2008, https://www.lanacion.com.ar/1003957-la-madre-de-todas-las-batallas-es-una-nueva-ley-de-radiodifusion), or "La Madre de Todas las Batallas Tuvo Otro Final", Clarin, February 18 ${ }^{\text {th }}, 2014$. https://www.clarin.com/opinion/madre-todas-batallas-final 0 BkhzcY1jPXe.html.
}

\footnotetext{
${ }_{11}$ Negative propaganda towards the end of political campaigns had been used previously by the Kirchners and their allies prior to several elections. See, for example, https://www.lanacion.com.ar/930962-se-retracto-el-autorde-la-falsa-denuncia-contra-olivera-en-2005, https://www.lanacion.com.ar/1128028-denuncias-y-escandalos-queestallaron-antes-de-otras-elecciones, and https://www.lanacion.com.ar/1127915-las-huellas-de-una-campanasucia.
12 Each rating point is estimated to represent about 100,000 viewers only in the Greater Buenos Aires area, but total national coverage could more than triple that amount (see https://chequeado.com/el-explicador/icomo-se- mide-el-rating-en-el-mundo/ and http://www.ibope.com.ar).

${ }_{13}$ Moreover, there were several corruption allegations regarding the funding of the "Soccer for All" program. See, for example, "Fútbol para Todos gastó 1200 millones de dólares sin control", La Nación, December 30, 2018.
} 
Another example of the use of the public media for political purposes was the TV show $6,7,8$, aired almost daily at the public TV channel. This show rabidly defended the policies of the government, and often included personal attacks on government critics. It had a unique and easily identifiable aesthetic and was often singled out as a unique example of the government's propaganda machine. Many incidents on the show were extensively reported in the media and it was widely seen as biased in favor of the government. ${ }^{14}$ Futbol para Todos and 6, 7, 8 in many occasions acted together, as advances of $6,7,8$ were aired during the halftime of the soccer games, and the show was broadcasted on Sundays right after the games exploiting audience inertia.

The propaganda campaign we study took place during the 2015 Argentine presidential election. $81.07 \%$ of the $32,130,853$ citizens listed in the electoral registry voted for six presidential candidates in the $1^{\text {st }}$ round election of October $25^{\text {th }}, 2015 .{ }^{15}$ There were $96.68 \%$ positive votes, and $3.32 \%$ blank/null votes. The Peronist candidate, former vice-president to Nestor Kirchner and incumbent governor of Buenos Aires, the largest province in the country, Daniel Scioli, obtained $37.08 \%$ of the positive votes, followed by businessman-turned-politician Mauricio Macri (34.15\%). Sergio Massa, the former chief of cabinet of the Cristina Kirchner administration, running on a platform that promised continuity with several of Kirchner's policies except for a tougher stand against crime and corruption, obtained $21.39 \% .{ }^{16}$ With no candidate obtaining $45 \%$ of the votes (nor $40 \%$ with a $10 \%$ difference on the runner-up), a runoff between Daniel Scioli and Mauricio Macri was called for November $22^{\text {nd }}$.

The first opinion polls right after the $1^{\text {st }}$ round showed a strong advantage for Macri of about 13 percentage points. ${ }^{17}$ Soon, a "dirty campaign" accusing Macri of continuity with the 1976-83 cruel military dictatorship and of being in favor of neoliberal policies was launched. The propaganda campaign started with an ad for the political show 6,7,8 that was first aired in Futbol para Todos on November $1^{\text {st }}$ during halftime of Boca-Tigre, a game which had very high ratings as it allowed Boca to win the season championship. It was then reproduced in other TV shows and media. ${ }^{18}$

\footnotetext{
${ }^{14}$ One example that describes some of these incidents is the article "Apologia de la Crueldad," by Ernesto Tenembaum, El Cronista, December 22, 2015, https://www.cronista.com/columnistas/Apologia-de-la-crueldad-20151222-0028.html.

${ }^{15}$ In Argentina, voting is allowed from age 16 on, but mandatory between ages 18 to 70 . However, enforcement of this obligation is weak.

${ }^{16}$ They were followed by three additional candidates: Nicolás del Caño (3.23\%), Margarita Stolbizer (2.51\%), and Adolfo Rodriguez Saá (1.64\%).

${ }^{17}$ See, for example, https://www.lapoliticaonline.com/nota/93556-primeros-numeros-del-ballotage-macri-seimpondria-por-casi-13-puntos/, and https://www.perfil.com/noticias/politica/la-primera-encuesta-da-ganador-amacri-sobre-scioli-1027-0057.phtml.

${ }^{18}$ See, https://www.youtube.com/watch?v=L6HBFRAXf08. Also, "El Gobierno defendió el uso de Futbol para Todos para atacar a Macri,” in La Politica Online, November 2, 2015.
} 
The propaganda campaign focused on the idea that Macri's government would "adjust" the economy by reducing spending and increasing taxes. This was portrayed as anti-labor and connected to the military dictatorship; a period when the labor share fell dramatically by more than ten percentage points (Galiani and Porto, 2010) after collective bargaining was suppressed, and union leaders were incarcerated, or even kidnapped and murdered. ${ }^{19}$ The initial ad of the show 6, 7, 8 that started the campaign had the heading "Enlightening Similarities." This referred to the similarities between the economic policies that Macri was allegedly planning to implement and the economic "plan" of Jose Alfredo Martinez de Hoz, the Minister of Economy of the military dictatorship and one of the most reviled men in Argentina's history.

Once the propaganda campaign started, those in charge of the Macri electoral team concluded that responding to it would be ineffective and limited their response. Iglesias Illa (2016), a member of Macri's team, in the November $2^{\text {nd }}$ entry of his campaign diary cites Marcos Peña, Macri's campaign lead manager, referring explicitly to the propaganda campaign: "The best, it is clear, is to do nothing. Or do almost nothing. Not being reactive, we do not have to talk about what they want us to." The same day, Peña insisted: "Let's not go into the fear campaign, let's not answer lies." Two days later, Jaime Durán Barba, Macri's campaign guru, also recommended: "It doesn't make any sense to reply anything...", although some campaign managers started to worry about the propaganda impact. ${ }^{20}$ Thus, Macri continued his "positive agenda," although one mild specific response was a TV ad describing what Macri would not do. Moreover, a short clip showing a young Scioli supporting Menem's neoliberal policies of the 1990's circulated on the social networks, probably aired by Macri's supporters. Eventually, Macri won the ballotage on November $22^{\text {nd }}, 2015$, by only 2.68 points ( $51.34 \%$ to $48.66 \%$ ).

\section{Data and Empirical Strategy}

\subsection{Data}

The data were obtained from Wonder, a marketing and public opinion consulting firm that, since 2008, engages a panel of subjects (called Wonderpanel) across the country who voluntarily fill out short surveys online in exchange for cash prizes and other rewards. ${ }^{21}$ After the general election of October $25^{\text {th }}, 2015$, and once the negative campaign started, the firm attempted to learn about its effects (and the best way to counteract it) by performing a randomized control trial on their panel population. Using data generated in the field has the

\footnotetext{
19 The labor share had reached 50\% in 1974 but it fell to a third of GDP during the dictatorship's first year (1976). The labor share had followed the opposite trajectory during the Kirchner administration, rising from 34.3\% in 2003 to $43.6 \%$ in 2008. See, for example, Silvia Stang, "La esquiva meta del fifty fifty: mitos y verdades de la distribución del ingreso," La Nación, January 27, 2013, https://www.lanacion.com.ar/1549178-la-esquiva-metadel-fifty-fifty-mitos-y-verdades-de-la-distribucion-del-ingreso.

${ }^{20}$ See Iglesias Illa (2016), p. 312, "Lo mejor, queda claro enseguida, es no hacer nada. O no hacer casi nada. El eje es no ser reactivo, dice Marcos, no tenemos que hablar de nada de lo que ellos quieren." See also pages 314, 318, and 321.

${ }^{21}$ For details, see http://wonderconsultora.com.ar/wonderpanel/ and http://www.wonderpanel.com/.
} 
advantage of being close to the actual experience of someone subject to an attempt at persuasion by propaganda. We do not know if the firm sold the results of this study to any of the political parties, but we do know that they were involved in other ways with the Macri campaign. ${ }^{22}$ We were acquainted with the owners of the firm, provided them with some suggestions, and were able to buy the unidentified data from them right after the ballotage.

1202 Wonderpanel participants fully completed the firm's survey, which was carried out during ten days from November $11^{\text {th }}$ to November $20^{\text {th }}$, within the interim period between the general election of October $25^{\text {th }}$ and the runoff election of November $22^{\text {nd }}$. It was an online survey without a human surveyor involved. Wonderpanel questionnaire is presented in the Online Appendix. Participants were first asked a short number of questions regarding their age, gender, education level, household head status, household head's educational level, and place of residence. Although the general election of October $25^{\text {th }}$ had already occurred, Wonder preferred not to prime the participants asking them before the treatment the electoral choice they had already made days ago. Instead, they measured proxies for participants' ideology before treatment through a set of indirect questions on whether the poor exert effort, the desired penalty for a crime, and whether Lionel Messi is a better soccer player than Diego Maradona. ${ }^{23}$

The firm regularly interacted with panel members online and was able to introduce a set of videos midway during the administration of the survey. Randomly, one third of subjects was asked to watch an institutional video on the electoral procedure used as a placebo (the control group), another third was asked to watch the negative campaign ad from the show $6,7,8$ (the treatment group), and the last third was split into three and asked to watch the $6,7,8$ negative campaign ad followed by three different "antidote" videos (the treatment + antidote group). The three different videos randomly used as antidotes for this last group were: a Macri's positive response (a video produced by the Macri campaign of him positively explaining his proposals), a Macri's defensive response (a video produced by the Macri campaign of him explaining what he would not do, with a rebuttal of the points raised in the attack video), and a "counterattack" video that circulated in the social networks at that time in which Daniel Scioli in an old interview defended the neoliberal policies of the Menem administration of the 1990 's. ${ }^{24}$ See the Online Appendix for a full description and transcript of the videos.

A questionnaire was completed after subjects watched the videos asking them how they intended to vote in the runoff round. Participants were also asked about their vote in the first

\footnotetext{
22 See, for example, https:/ / www.cronista.com/elecciones2015/La-firma-que-acerto-en-la-Ciudad-dice-que-ganaMacri-20150728-0015.html, and https://www.iprofesional.com/notas/216613-La-encuestadora-que-acerto-elresultado-porteno-afirma-que-Macri-ganaria-en-balotaje.

${ }^{23}$ It is possible to imagine Macri's voters to favor Lionel Messi over Diego Maradona given his introverted nature, the time he spent in his formative years in Europe, and Maradona's public support for Fidel Castro and Hugo Chavez. Indeed, the variable Messi is Better is positively correlated with intention to vote for Macri in the control group.

${ }^{24}$ This video circulated in the social networks before the runoff, either spontaneously or as a part of an informal campaign developed by Macri.
} 
election round, whether they thought Macri believed that lowering wages was necessary, their opinion of Macri, and whether they would rather make a donation to a soup kitchen sponsored by Macri or by Scioli. Naturally, all the responses surveyed after the videos are potentially affected by watching them. Participants were not asked whether they had already seen the videos before the experiment.

In addition to the 1202 participants who fully completed the survey, 69 participants interrupted their participation in the experiment after the beginning of the videos but before the end of the survey, without providing an explanation. 61 of them interrupted before declaring their intention to vote in the ballotage, whereas 8 participants declared their ballotage vote intention, but interrupted the survey before answering about their first round vote. The frequency of interruption is higher for the treatment group $(6.08 \%)$ than for the control group $(4.07 \%)$, although the t-test does not reject the null hypothesis of equality of means at conventional levels (the p-value equals 0.1374). ${ }^{25}$

Table 1 presents the pre-treatment characteristics of the experiment participants for the total sample of 1271 participants (the 1202 who completed the survey and the 69 who interrupted it). The first column shows the means and standard deviations of the pre-treatment characteristics of the control group. The other columns provide the coefficients and standard errors of regressing the characteristics on treatment status, first for all the treated arms together, and then disaggregating the treatment into propaganda only and propaganda plus each antidote dummies. There are no significant differences in observable characteristics across the samples suggesting that the randomization was successful and, therefore, it is also reasonable to assume that unobservables are also balanced across groups.

Table 2 compares the pre-treatment characteristics by treatment status only for the 1202 participants who fully completed the survey. Again, the first column shows the means and standard deviations of the pre-treatment characteristics of the control group, and the other columns provide the coefficients and standard errors of regressing the characteristics on treatment status. Again, there are no significant differences in observable characteristics across the samples suggesting that the randomization was successful.

As expected for an online survey, the sample is not representative of the population. About half of the Argentine households had internet access in 2015, whereas all the participants had it (at home or at work) in this experiment. Moreover, the average years of education for 2015 for the Argentine urban population was 11.92 years for adults, and 11.66 years for household heads, whereas these figures are 16.29 and 16.15, respectively, in our sample. Thus,

\footnotetext{
${ }^{25}$ Other 71 participants declared they were not able to watch and/or listen to the videos for technical reasons. The reasons provided were: bad connectivity/the video did not download/the video did not open (38 cases), they were not allowed to open/listen videos at work (15 cases), audio problems/no headphones (14 cases), or other reasons (4 cases). The probability of reporting these technical problems is highly uncorrelated with treatment status. These technical attrition rates are $5.66 \%$ in the control group and $5.53 \%$ in the treatment group, and the pvalue associated to the t-test of no differences of means is 0.9274 .
} 
the experiment participants are more educated, and, thus, probably richer, than the average Argentine.

\subsection{Empirical Strategy}

In our main analysis, we estimate regressions of the form

$$
\text { Vote }_{i}=a+b \text { Propaganda }_{i}+c \text { Antidote }_{i}+d \text { Controls }_{i}+\mu_{i}
$$

where: Vote is person's $i$ answer to the question "Who will you vote for in the ballotage of November 22 2 nd?", which has four possible answers (Daniel Scioli, Mauricio Macri, Blank or I don't know). We group Blank and I don't know into one category and report the results for the three alternatives separately so as to study the distribution of vote intentions post treatment, as it is interesting to learn if propaganda may lead to more Scioli votes or simply to more uncertain voters. The errors in the three equations are (by construction) statistically dependent, so we estimate the parameters by means of Seemingly Unrelated Regressions (SUR). Propaganda is a dummy variable indicating whether person $i$ viewed the ad against Macri extracted from the government sponsored TV show. This video was presented to the participants in the four treatment arms (i.e., alone and also in combination with each one of three antidotes). Antidote is $_{i}$ a dummy variable indicating whether person $i$ also viewed any of the three antidotes aimed to neutralize the negative effect of political propaganda. They are also disaggregated into three dummies: Antidote $1_{i}$ (the positive ad from the Macri campaign), Antidote $2_{i}$ (the ad developed by the Macri campaign as an answer to the negative campaign launched by the government), and Antidote $3_{i}$ (the video clip of an old interview of Daniel Scioli in the 1990's when he was defending neoliberal policies, including privatizations). Identification of the average causal effect of propaganda is based on the random assignment of subjects to treatment arms by the marketing firm.

\section{Main Results}

Tables 3 and 4 present the main results of our paper. In Table 3, we analyze the effect of the propaganda video, regardless of whether participants were also exposed to the antidotes. In columns 1-3, Macri's declared vote intention dropped by 7.5 percentage points when participants are exposed to the negative campaign video, while the proportion voting for Cristina Kirchner's candidate, Daniel Scioli, increased 2.9 percentage points, and the proportion undecided/blank increased by 4.6 percentage points.

In columns 4-6, we control for pre-treatment variables. As explained above, participants

were not asked before the videos about the presidential candidate they voted in the first round in order to avoid priming them with electoral questions. However, the pre-treatment controls include three variables that could proxy for ideological preferences of the survey participants: Poor Don't Make Effort (a dummy variable that equals one if the respondent thinks that poor 
people are poor because they do not make effort); Penalty (the number of months that the respondent considers that a 20 -year-old man should be in prison if he is found guilty of robbery for the second time); and Messi is Better (a dummy variable that equals one if the respondent thinks that Messi is a better soccer player than Maradona). ${ }^{26}$

When we control for all pre-treatment variables in columns 4-6 of Table 3, results are very similar. Watching the negative campaign video decreases Macri's vote intention by 6.5 percentage points, increases Scioli's votes by 2 percentage points, and the proportion of undecided/blank increases by 4.5 percentage points. The reduction in Macri's vote intention represents 11.2 percent of the preference for his candidacy in the control group. Our conclusion is that the propaganda campaign seems effective in persuading a large group of subjects to reduce their declared support for Macri.

It is useful to calculate the persuasion rate for comparison with other estimates in the literature presented in della Vigna and Gentzkow (2010). This rate reports the percentage of receivers that change their views within the group of receivers not already persuaded. In other words, considering the intention to vote for Macri as a binary outcome, $e_{i}$ the share of group $i$ receiving the message, and $y_{i}$ the share of group $i$ adopting the desired beliefs, the persuasion rate $f$ captures the effect of the persuasion treatment on beliefs $\left(y_{T}-y_{C}\right.$, with $y_{T}=0.515$ and $y_{C}=0.58$ in our sample) adjusting for exposure to the message $\left(e_{T}-e_{C}\right)$ and for the size of the population that is not yet convinced $\left(1-y_{C}\right)$ :

$$
f=100 * \frac{y_{T}-y_{C}}{e_{T}-e_{C}} \frac{1}{1-y_{C}} ; f=100 * \frac{0.515-0.58}{100-0} \frac{1}{0.58}=-0.112
$$

Assuming zero exposure in the control group, the (anti-Macri) persuasion rate is approximately $11.2 \%$, which is in the mid-range of the persuasion rates reported in della Vigna and Gentzkow (2010). This assumption is unlikely to be valid as some survey participants could have been exposed to the propaganda campaign through other media (for example, those subjects interested in soccer), but it may be more reasonable for groups that in Argentina are traditionally less interested in soccer, watch less open TV, or are less interested in politics in general. Note that the more people have been exposed in the control group, the higher the persuasion rate for a given estimate of the treatment effect.

Table 4 studies the effects of the three different types of defenses or "antidotes" considered by the Macri campaign on the individuals exposed to the propaganda. The first three columns consider the three antidotes together, while the last three columns disaggregate the positive response, the defensive response, and the counterattack. All regressions control for pretreatment characteristics. The results suggest that the antidotes are unable to counterbalance the

\footnotetext{
${ }^{26}$ Note that, although all p-values are above conventional values in the second column of Table 2 , the coefficient on the variable Messi is Better is relatively large (4.5 percentage points).
} 
negative effect of the propaganda campaign. While the estimated effect of the negative propaganda campaign remains virtually unchanged, watching the antidotes does not have an impact on vote intentions for the runoff. This is true both when the antidotes are considered in combination or separately, although the groups of subjects exposed to each antidote are smaller in number so the statistical power behind these comparisons is lower. The Macri campaign managers seemed to have been right when pondering that replies to the propaganda campaign would be ineffective. Some of them were also rightly worried about the damaging effect of the campaign. ${ }^{27}$ In summary, Tables 3 and 4 show that subjects who watched the propaganda campaign were less likely to report that they would vote for Macri in the ballotage.

\section{Further Results: Heterogeneous Effects, Mechanisms, and Robustness}

We next explore the presence of heterogeneous effects by gender. Galasso and Nannicini (2016) find significant gender differences in reactions to negative campaigns. The Online Appendix Tables A1 through A4 report some differences in pre-treatment characteristics between the two gender sub-samples -for example, women are younger than men and less likely to be the household head-, but treatment and control groups are similar across observables within each gender sample, suggesting that the randomization was also successful at that level, both with and without including the attrited observations.

Table 5 shows that the propaganda effects are quite different across genders. While there are no detectable effects of the propaganda campaign in the men sub-sample, there are large and precisely estimated effects in the women sub-sample. The size is large: women are almost 12 percentage points less likely to support Macri when exposed to the ad. Most of the increase appears on the undecided/blank category. The persuasion rate for men is zero due to insignificant estimated treatment effects, while that for women is $20.3 \% \quad y_{T}=0.4638$, and $y_{C}=0.5818$ ), assuming again zero exposure in the control group. These heterogeneous gender results could be capturing differences in prior exposure to the campaign, although the "ads" were widely circulated (even outside the transmission of the soccer matches) and the available evidence suggests that, even though men watch more soccer than women, the difference is not large (according to the rating company IBOPE the gender proportion for audience of soccer games in open TV for November 2015 is about 60:40 in favor of men). A more plausible explanation to the gender differences is that women are more sensitive to the social consequences of economic adjustments suggested by the propaganda as there is some evidence that they tend to be more left wing -see the political gender gap documented in Alesina and La Ferrara (2005) and Edlund and Pande (2002), and Niederle (2016) for a review-. ${ }^{28}$

\footnotetext{
27 See Iglesias Illa (2016), p. 321 and footnote 20 above.

${ }^{28}$ The propaganda effect also seems somewhat stronger for younger participants (and not just because women are younger in our sample).
} 
Table 6 explores the mechanism of persuasion and, in particular, a potentially higher concern of women to Macri lowering wages. The first three columns study if subjects believed one of the main parts of the ad, showing a very young Macri being interviewed in his role of businessperson and explaining that it was important to lower costs and that wages were a part of costs. It appears that there is no effect on the overall sample, but again there is some evidence that women are about 6 percentage points more likely to report that the criticism on Macri is pertinent and that he thinks lowering wages is a valid option. This supports the idea that the propaganda campaign was effective in persuading subjects to change their views about Macri in the women subsample. ${ }^{29}$ The last three columns consider the respondents' Opinion on Macri (in a 1 to 10 cardinal scale) as an alternative dependent variable. Again, the propaganda shows an effect in the women subsample. ${ }^{30}$

Finally, we considered alternative strategies to deal with the fact that a group of participants interrupted their participation in the experiment after the beginning of the videos but before the end of the survey. As explained above, 61 participants left the online survey for no technical reasons before declaring their intention to vote in the ballotage, whereas 8 participants declared their ballotage vote intention, but interrupted the survey before answering their first-round vote. As noted above, there is more attrition in the treatment than in the control group, although the difference is not significant at conventional levels. But it is useful to consider the possibility that all of the difference is caused by the treatment, perhaps because the attrited are Macri supporters who found the ad upsetting. One strategy is imputing as Macri voters all 45 participants in the treatment group who did not declare their runoff vote intention. For the control group, we can predict the votes of the 16 subjects that interrupted the survey using the coefficients from a multinomial Logit model (given that those that did not declare to vote for Macri had two options: Scioli or undecided/blank) estimated on the control group. This strategy exploits the fact that the control group was exposed to a neutral video, so the attrition rate in this group can arguably be ignored conditional on observable covariates, which is what the implemented methodology exploits. The results in Table 7 show, again, a negative effect of the propaganda campaign on Macri's ballotage support, and that the effect comes from the women subsample. ${ }^{31}$

\footnotetext{
${ }^{29}$ There are several channels through which persuasion might take place. See Chong, Duryea and La Ferrara (2012) for the effect of soap operas on fertility in Brazil, and Durante, Pinotti and Tesei (2017) for evidence that individuals with earlier access to Berlusconi's all entertainment channel were more likely to vote for him in the 1994 Italian election.

${ }^{30}$ A weakness of the survey is that it collects only opinions rather than actions, and these could be considered a weaker indication of actual preferences. The closest it comes to collect an action is a hypothetical question regarding the desire to donate to an NGO connected to Macri or to one connected to Scioli. The results using this question are weaker statistically, but consistent qualitatively with our main results (see Online Appendix Table $5)$.

31 Similar results are obtained under other imputation rules such as assigning all the attrited participants (in both treatment and control groups) to Macri votes, or using the multinomial Logit model for imputing all the attrited observations.
} 
Another possible strategy is to include further controls for ideological differences. A demanding approach is to add a set of dummy variables capturing the respondent's vote in the first-round election. Remember, however, that the survey question regarding first-round vote was included after the videos (in order to avoid priming subjects with the election). Thus, the estimated coefficients on the first-round declared votes could be capturing the effect of the treatment itself, so this approach is also conservative. When we perform this exercise for the whole sample in the first three columns of Table 8 , the coefficient on watching the propaganda video declines in absolute value to 3.9 percentage points, but it is still statistically significant at standard levels. The rest of Table 8 shows that the strong gender differences are robust to controlling for first-round declared vote.

\section{Conclusions}

In this paper we study data generated during the weeks prior to the 2015 Argentine runoff presidential election, when the propaganda machine set up by the governments of Nestor and Cristina Kirchner over the period 2003-15 was used to attack the opposition candidate and influence voter preferences. Two aspects of this setting are noteworthy. First, the consensus about the heavy pro-government bias in the media, which was defended by most politicians, intellectuals and journalists that supported the government as well as denounced by those in the opposition. Thus, most people were aware of media bias when they consumed government propaganda. Second, the propaganda messages reached citizens regardless of their political inclination. Specifically, the propaganda machine influenced a large number of media outlets, either directly through ownership by the State or regime insiders, or indirectly through the discretional distribution of subsidies. Moreover, the Cristina Kirchner administration nationalized the transmission of soccer matches in 2009, eliminating pay-per-view fees under a TV show called Soccer for All, and replacing commercial ads by government "ads", including those at halftime. This allowed the government's propaganda to reach most citizens and not just those that were already close ideologically. These features provide a setting were the effectiveness

of propaganda is unlikely to be observed because consumers ought to be able to discount biased messages.

In spite of this, the data reveal strong persuasion effects of propaganda: treated subjects are 6.5 percentage points less likely to report they will vote for the challenger, two percentage points more likely to vote for the incumbent party's candidate, and 4.5 more likely to report to be undecided. These effects are consistent with the evolution of opinion polls at that time. Immediately after the $1^{\text {st }}$ round election, the challenger Mauricio Macri was expected to obtain a comfortable victory. Once the government's propaganda machine was set in full motion, Daniel Scioli of the incumbent Peronist party almost closed the gap, and Macri finally won the presidency by a small margin. The results are also consistent with the "do nothing" recommendation of Macri's political analysts at the time: the three strategies considered to fend off the attack are ineffective. Moreover, there is some evidence that subjects believed the main 
accusation contained in the propaganda campaign (that Macri would lower wages). The results are driven by women: the estimated coefficient in the women sub-sample is twice the size as in the full sample and precisely estimated, whereas in the men sub-sample it is small and statistically insignificant.

The causal interpretation of these estimates is reasonably supported by the characteristics of the data: it was produced by a marketing firm who performed a randomized control trial to learn about the propaganda campaign just prior to the 2015 presidential runoff election. A group of subjects that had regular contact with the firm was treated with one of the key pieces of propaganda employed in the campaign: an ad for 6, 7, 8, a controversial state-sponsored TV show that "explained" the similarities between Macri and the economic program of the Argentine military dictatorship. Subjects then answered a follow-up survey on their vote intentions. Some of them were also asked to watch the responses of the Macri campaign. While not as clean as data generated in a lab experiment, the pre-treatment characteristics are balanced across groups so the randomization appears to have been successful.

Our study, however, has two clear limitations. First, the outcome variable is reports on vote intentions, rather than actual votes. While there is value in studying self-reported votes, it would be preferable to base our conclusions on revealed preferences. The second problem is that it is difficult to know what mechanism gives rise to the observed gender differences. While this is also true in previous studies, it would be considerably more satisfactory to learn what the exact source of gender differences is in the impact of a particular treatment (in this case, propaganda). On the positive side, our study has a reasonable combination of internal validity and data obtained in the field, so we can be relatively confident that the forces at play truly involve propaganda as observed in political settings. Thus, if combined with other unbiased local experiments, our study provides a realistic basis to construct externally valid estimates of the effects of political propaganda in weak institutional settings. 


\section{References}

Adena, Maja, Enikolopov, Ruben, Petrova, Maria, Santarosa, Veronica and Zhuravskaya, Ekaterina, (2015), "Radio and the Rise of the Nazis in Prewar Germany," Quarterly Journal of Economics, 130 (4): 1885-1939.

Alesina, Alberto and Eliana La Ferrara (2005), "Preferences for Redistribution in the Land of Opportunities," Journal of Public Economics, v. 89(5-6, Jun), 897-931.

Ansolabehere, Stephen D., Shanto Iyengar, and Adam Simon (1999), "Replicating Experiments Using Aggregate and Survey Data: The Case of Negative Advertising and Turnout," American Political Science Review 93: 901-9.

Baum, Matthew A. (2002), "Sex, Lies, and War: How Soft News Brings Foreign Policy to the Inattentive Public," American Political Science Review 96: 91-109.

Besley, Tim and Prat, Andrea (2006), "Handcuffs for the Grabbing Hand? Media Capture and Government Accountability,” American Economic Review, 96(3):720-36.

Chong, Alberto, Suzanne Duryea, and Eliana La Ferrara (2012), "Soap Operas and Fertility: Evidence from Brazil", American Economic Journal: Applied Economics, 4(4), 1-31.

Da Silveira, Bernardo S. and João M. P. De Mello (2011), "Campaign Advertising and Election Outcomes: Quasi-natural Experiment Evidence from Gubernatorial Elections in Brazil," The Review of Economic Studies, Volume 78, Issue 2, 1, pp 590-612.

della Vigna, Stefano, and Ethan Kaplan. (2007), “The Fox News Effect: Media Bias and Voting," Quarterly Journal of Economics 122: 1187-1234.

della Vigna, Stefano and Matthew Gentzkow (2010), "Persuasion: Empirical Evidence”, Annual Review of Economics, Vol. 2.

della Vigna, S., R. Enikolopov, V. Mironova, M. Petrova, and E. Zhuravskaya (2014), "Cross-border media and nationalism: Evidence from Serbian radio in Croatia," American Economic Journals: Applied Economics, 6(3), 103-32.

Di Tella, Rafael, Sebastian Galiani, and Ernesto Schargrodsky (2012), "Reality versus Propaganda in the Formation of Beliefs about Privatization," Journal of Public Economics 96 (5-6): 553-67.

Di Tella, Rafael and Ignacio Franceschelli, (2011), "Government Advertising and Media Coverage of Corruption Scandals," American Economic Journal: Applied Economics, October, 3 (4), 119-51.

Djankov, S., C. McLeish, T. Nenova, and A. Shleifer (2003), "Who Owns the Media?," Journal of Law and Economics, 46(2).

Durante, Ruben and Brian Knight (2012), "Partisan Control, Media Bias, and Viewer Responses: Evidence from Berlusconi's Italy", Journal of the European Economic Association, 10 (3), pp. 451481.

Durante, R., Pinotti, P. and Tesei, A. (2017), “The Political Legacy of Entertainment TV”, CEPR Working Paper DP \#10738. 
Edlund, L., and R. Pande (2002), "Why Have Women Become Left-Wing? The Political Gender Gap and the Decline in Marriage," Quarterly Journal of Economics, 117: 917-961.

Enikolopov, R., M. Petrova, and E. Zhuravskaya (2011), "Media and political persuasion: Evidence from Russia," American Economic Review 101(7), 3253-3285.

Egorov, Georgy, Sergei Guriev, and Konstantin Sonin (2009), "Why Resource-Poor Dictators Allow Freer Media: A Theory and Evidence from Panel Data." American Political Science Review, 103(4), 645-668.

Galasso, Vincenzo and Nannicini, Tommaso (2016), "Persuasion and Gender: Experimental Evidence from Two Political Campaigns," CESifo Working Paper Series No. 5868.

Galiani, S. and G. Porto (2010), "Trends in tariff reforms and in the structure of wages", Review of Economics and Statistics, Volume 92, pages 482-494.

Gentzkow, M. and Shapiro, J. (2004), "Media, Education and Anti-Americanism in the Muslim World," Journal of Economic Perspectives, 18(3): 117-33.

Gentzkow, Matt, Petek, Nathan, Shapiro, Jesse M. and Michael Sinkinson (2015), "Do Newspapers Serve the State? Incumbent Party Influence on the US Press, 1869-1928", Journal of the European Economic Association, 13(1): 29-61.

Gerber, Alan, James Gimpel, Donald Green and Daron Shaw (2011), "How Large and Long-lasting Are the Persuasive Effects of Televised Campaign Ads? Results from a Randomized Field Experiment", The American Political Science Review, Vol. 105 (1), pp. 135-150.

Gervasoni, Carlos and María Laura Tagina (2019), "Explaining Support for the Incumbent in Presidential Elections," in Lupu, Noam, Virginia Oliveros, and Luis Schiumerini (Eds.), Campaigns and Voters in Developing Democracies: Argentina in Comparative Perspective. Ann Arbor: Michigan University Press, pp. 114-135.

Glaeser, E. (2005), “The Political Economy of Hatred,” Quarterly Journal of Economics, 120(1):45-86.

Green, Donald P., and Alan S. Gerber (2015), Get Out the Vote. Brookings Institution Press.

Grinberg, Ivan (2015), "En tu Cabeza hay un Gol: La experiencia de los espectadores hacia la publicidad oficial de Fútbol para Todos", Tesis de Grado 23128, UDESA.

Huber, G. A. and Arceneaux, K. (2007), "Identifying the Persuasive Effects of Presidential Advertising." American Journal of Political Science, 51: 957-977.

Iglesias Illa, Hernán (2016), Cambiamos. Sudamericana, Buenos Aires.

Iyengar, S., Peters, M. D., Kinder, D. R. (1982), "Experimental demonstrations of the 'not-so-minimal' consequences of television news programs," American Political Science Review 76 (4), 848-58.

Katz, E., Feldman, J. (1962), "The debates in the light of research: a survey of surveys". In: Krauss, S. (Ed.), The Great Debates. Indiana University Press, Bloomington.

Klapper, J. (1960), The Effects of Mass Communication. Free Press, Glencoe, Il. 
Knight, Brian and Ana Tribin (2019a), “The Limits of Propaganda: Evidence from Chavez's Venezuela", Journal of the European Economic Association 17(2), 567-605.

Knight, Brian and Ana Tribin (2019b), "Opposition Media, State Censorship, and Political Accountability: Evidence from Chavez's Venezuela”, NBER Working Paper No. 25916.

Lasswell, H. (1927), “The Theory of Political Propaganda,” American Political Science Review 21 (3), 62731.

Lau, R. R., Sigelman, L. and Rovner, I. B. (2007), "The Effects of Negative Political Campaigns: A Meta-Analytic Reassessment," Journal of Politics, 69: 1176-1209.

Niederle, M., (2016), “Gender”, in J. Kagel and A. E. Roth (eds.), Handbook of Experimental Economics, second edition.

Paluck, E. L. (2009), "Reducing Intergroup Prejudice and Conflict Using the Media: A Field Experiment in Rwanda," Journal of Personality and Social Psychology, 96 (March): 574-587

Patterson, T. E., McClure, R. D. (1976), The Unseeing Eye: The Myth of Television Power in National Elections, G. P. Putnam, New York.

Pons, Vincent (2018), "Will a Five-Minute Discussion Change Your Mind? A Countrywide Experiment on Voter Choice in France," American Economic Review 108, no. 6 (June): 1322-1363.

Prat, Andrea and David Stromberg (2013), “The Political Economy of Mass Media”, in Advances in Economics and Econometrics: Volume 2, Applied Economics: Tenth World Congress, Volume 50, pp. 135. Cambridge University Press.

Qian, Nancy and David Yanagizawa-Drott (2017), "Government Distortion in Independently Owned Media: Evidence from U.S. Cold War News Coverage of Human Rights". Journal of the European Economic Association, Volume 15, Issue 2, pp. 463-499.

Sears, D. O., Chaffee, S. H. (1979), "Uses and Effects of the 1976 Debates: an Overview of Empirical Studies”. In: Krauss, S. (Ed.), The Great Debates, 1976: Ford vs. Carter. Indiana University Press, Bloomington.

David Yanagizawa-Drott (2014), "Propaganda and Conflict: Evidence from the Rwandan Genocide," The Quarterly Journal of Economics, Volume 129, Issue 4 (November): 1947-1994. 


\section{Table 1: Pre-treatment Characteristics - Original Sample (including participants with incomplete answers)}

\begin{tabular}{lcccccc}
\hline \hline \multirow{4}{*}{ Variables } & $(1)$ & $(2)$ & $(3)$ & $(4)$ & $(5)$ & $(6)$ \\
\cline { 2 - 6 } & Control & Propaganda & $\begin{array}{c}\text { Propaganda } \\
\text { only }\end{array}$ & $\begin{array}{c}\text { Propaganda } \\
\text { + Antidote1 }\end{array}$ & $\begin{array}{c}\text { Propaganda } \\
\text { + Antidote2 }\end{array}$ & $\begin{array}{c}\text { Propaganda } \\
\text { + Antidote3 }\end{array}$ \\
\hline Age & 43.871 & -0.587 & -1.097 & 0.527 & -1.506 & 0.734 \\
Gender & $(11.990)$ & $(0.704)$ & $(0.797)$ & $(1.168)$ & $(1.081)$ & $(1.149)$ \\
Household Head & 0.448 & 0.004 & -0.036 & 0.045 & 0.041 & 0.048 \\
& $(0.498)$ & $(0.030)$ & $(0.034)$ & $(0.048)$ & $(0.049)$ & $(0.049)$ \\
Years of Education & 0.626 & 0.010 & 0.015 & -0.003 & 0.009 & 0.007 \\
& $(0.484)$ & $(0.029)$ & $(0.033)$ & $(0.047)$ & $(0.048)$ & $(0.047)$ \\
HH - Years of Education & 16.398 & -0.129 & -0.183 & -0.220 & 0.025 & -0.017 \\
& $(2.158)$ & $(0.130)$ & $(0.153)$ & $(0.210)$ & $(0.204)$ & $(0.217)$ \\
Buenos Aires City & 16.252 & -0.144 & -0.293 & -0.087 & 0.164 & -0.043 \\
& $(2.456)$ & $(0.149)$ & $(0.179)$ & $(0.240)$ & $(0.217)$ & $(0.254)$ \\
Greater Buenos Aires & 0.422 & -0.030 & -0.026 & -0.059 & -0.028 & -0.012 \\
& $(0.494)$ & $(0.029)$ & $(0.034)$ & $(0.047)$ & $(0.048)$ & $(0.048)$ \\
Messi is Better & 0.314 & 0.020 & 0.026 & 0.021 & 0.007 & 0.010 \\
& $(0.465)$ & $(0.028)$ & $(0.032)$ & $(0.045)$ & $(0.046)$ & $(0.046)$ \\
Poor Don't Make Effort & 0.525 & -0.035 & -0.051 & 0.002 & -0.007 & -0.050 \\
& $(0.500)$ & $(0.030)$ & $(0.034)$ & $(0.048)$ & $(0.049)$ & $(0.049)$ \\
Penalty & 0.216 & 0.009 & 0.011 & 0.024 & -0.019 & 0.014 \\
& $(0.412)$ & $(0.025)$ & $(0.029)$ & $(0.041)$ & $(0.040)$ & $(0.041)$ \\
Number of Observations & $(21.971$ & -1.674 & -1.395 & -0.499 & -2.066 & $-3.388^{*}$ \\
in each group & 417 & $(1.264)$ & $(1.452)$ & $(2.047)$ & $(1.993)$ & $(1.985)$ \\
\hline \hline
\end{tabular}

Notes: Column (1) reports the means (and, in parentheses, their standard deviations) for the pre-treatment characteristics in the control group. The following columns provide the coefficients and robust standard errors of regressing the characteristics on a treatment dummy, considering all treatment branches together in Column (2), and then disaggregating the treatment into propaganda only and propaganda plus antidote dummies (Propaganda only, Propaganda + Antidote 1, Propaganda + Antidote 2, and Propaganda + Antidote 3) in columns (3) to (6). Age is the age of the respondent. Gender is a dummy variable that equals one if the respondent is male, and zero if the respondent is female. Household Head is a dummy variable that equals one if the respondent self-defines as the head of the household, and zero otherwise. Years of Education is the education level of the respondent. HH - Years of Education is the education level of the household head. Buenos Aires City is a dummy variable that equals one if the respondent lives in Buenos Aires City. Greater Buenos Aires is a dummy variable that equals one if the respondent lives in Greater Buenos Aires. Messi is Better is a dummy variable that equals one if the respondent thinks that Lionel Messi is a better soccer player than Diego Maradona. Poor Don't Make Effort is a dummy variable that equals one if the respondent thinks that poor people are poor because they do not make effort. Penalty is the number of months that the respondent considers that a 20 -year-old man should be in prison if he is found guilty of robbery for the second time. The last row indicates the number of observations considered in each group, but all the regressions are run with the 1271 observations. * Significant at $10 \%$. 
Table 2: Pre-treatment Characteristics - Main Sample

\begin{tabular}{lcccccc}
\hline \hline Variables & $\begin{array}{c}(1) \\
\text { Control }\end{array}$ & $\begin{array}{c}(2) \\
\text { Propaganda }\end{array}$ & $\begin{array}{c}(3) \\
\text { Propaganda } \\
\text { only }\end{array}$ & $\begin{array}{c}(4) \\
\text { Propaganda } \\
\text { + Antidote } 1\end{array}$ & $\begin{array}{c}(5) \\
\text { Propaganda } \\
\text { + Antidote2 }\end{array}$ & $\begin{array}{c}(6) \\
\text { Propaganda } \\
\text { + Antidote3 }\end{array}$ \\
\hline Age & 43.988 & -0.757 & -1.133 & -0.226 & -1.555 & 0.632 \\
Gender & $(12.051)$ & $(0.724)$ & $(0.826)$ & $(1.190)$ & $(1.104)$ & $(1.177)$ \\
Household Head & 0.450 & 0.006 & -0.033 & 0.050 & 0.050 & 0.035 \\
& $(0.498)$ & $(0.030)$ & $(0.035)$ & $(0.050)$ & $(0.050)$ & $(0.050)$ \\
Years of Education & 0.628 & 0.007 & 0.020 & -0.016 & 0.007 & -0.008 \\
& $(0.484)$ & $(0.030)$ & $(0.034)$ & $(0.049)$ & $(0.048)$ & $(0.049)$ \\
HH - Years of Education & 16.370 & -0.114 & -0.188 & -0.176 & 0.033 & 0.018 \\
& $(2.171)$ & $(0.133)$ & $(0.156)$ & $(0.219)$ & $(0.207)$ & $(0.222)$ \\
Buenos Aires City & 16.218 & -0.105 & -0.240 & -0.061 & 0.156 & -0.009 \\
& $(2.481)$ & $(0.154)$ & $(0.183)$ & $(0.253)$ & $(0.221)$ & $(0.261)$ \\
Greater Buenos Aires & 0.425 & -0.027 & -0.025 & -0.052 & -0.037 & 0.000 \\
& $(0.495)$ & $(0.030)$ & $(0.035)$ & $(0.049)$ & $(0.049)$ & $(0.049)$ \\
Messi is Better & 0.315 & 0.007 & 0.015 & 0.006 & 0.006 & -0.016 \\
& $(0.465)$ & $(0.029)$ & $(0.033)$ & $(0.047)$ & $(0.047)$ & $(0.046)$ \\
Poor don't make Effort & 0.533 & -0.045 & $-0.063 *$ & -0.003 & -0.010 & -0.070 \\
& $(0.500)$ & $(0.031)$ & $(0.035)$ & $(0.050)$ & $(0.050)$ & $(0.050)$ \\
Penalty & 0.215 & 0.013 & 0.018 & 0.024 & -0.014 & 0.016 \\
& $(0.411)$ & $(0.025)$ & $(0.030)$ & $(0.042)$ & $(0.040)$ & $(0.042)$ \\
Number of Observations & $(21.758$ & -1.513 & -1.215 & -0.690 & -2.078 & -2.660 \\
in each group & 400 & 802 & 400 & 134 & 134 & 134 \\
\hline \hline
\end{tabular}

Notes: Column (1) reports the means (and, in parentheses, their standard deviations) for the pre-treatment characteristics in the control group. The following columns provide the coefficients and robust standard errors of regressing the characteristics on a treatment dummy, considering all treatment branches together in Column (2), and then disaggregating the treatment into propaganda only and propaganda plus antidote dummies (Propaganda only, Propaganda + Antidote 1, Propaganda + Antidote 2, and Propaganda + Antidote 3) in columns (3) to (6). Age is the age of the respondent. Gender is a dummy variable that equals one if the respondent is male, and zero if the respondent is female. Household Head is a dummy variable that equals one if the respondent self-defines as the head of the household, and zero otherwise. Years of Education is the education level of the respondent. HH - Years of Education is the education level of the household head. Buenos Aires City is a dummy variable that equals one if the respondent lives in Buenos Aires City. Greater Buenos Aires is a dummy variable that equals one if the respondent lives in Greater Buenos Aires. Messi is Better is a dummy variable that equals one if the respondent thinks that Lionel Messi is a better soccer player than Diego Maradona. Poor Don't Make Effort is a dummy variable that equals one if the respondent thinks that poor people are poor because they do not make effort. Penalty is the number of months that the respondent considers that a 20 -year-old man should be in prison if he is found guilty of robbery for the second time. The last row indicates the number of observations considered in each group, but all the regressions are run with the 1202 observations with complete answers. * Significant at $10 \%$. 
Table 3: Effects of Propaganda

\begin{tabular}{ccccccc}
\hline \hline \multirow{2}{*}{ Variables } & $\mathbf{( 1 )}$ & $\mathbf{( 2 )}$ & $\mathbf{( 3 )}$ & $\mathbf{( 4 )}$ & $\mathbf{( 5 )}$ & $\mathbf{( 6 )}$ \\
& $\begin{array}{c}\text { Will Vote } \\
\text { Macri }\end{array}$ & $\begin{array}{c}\text { Will Vote } \\
\text { Scioli }\end{array}$ & $\begin{array}{c}\text { Doesn't Know } \\
\text { / Will Vote } \\
\text { Blank }\end{array}$ & $\begin{array}{c}\text { Will Vote } \\
\text { Macri }\end{array}$ & $\begin{array}{c}\text { Will Vote } \\
\text { Scioli }\end{array}$ & $\begin{array}{c}\text { Doesn't Know } \\
\text { / Will Vote } \\
\text { Blank }\end{array}$ \\
\hline Propaganda & $-0.075^{* *}$ & 0.029 & $0.046^{*}$ & $-0.065^{* *}$ & 0.020 & $0.045^{*}$ \\
Constant & $(0.030)$ & $(0.025)$ & $(0.027)$ & $(0.030)$ & $(0.024)$ & $(0.027)$ \\
& 0.580 & 0.187 & 0.233 & 0.061 & 0.495 & 0.444 \\
Observations & $(0.025)$ & $(0.020)$ & $(0.022)$ & $(0.125)$ & $(0.101)$ & $(0.113)$ \\
Controls & 1,202 & 1,202 & 1,202 & 1,202 & 1,202 & 1,202 \\
\hline \hline
\end{tabular}

Notes: Seemingly unrelated regression (SUR) estimates. Standard errors in parentheses. Will Vote Macri is a dummy variable that equals 1 if the respondent declares she/he will vote for Macri in the ballotage of November $22^{\text {nd }}$, and zero otherwise. Will Vote Scioli is a dummy variable that equals 1 if the respondent declares she/he will vote for Scioli in the ballotage of November $22^{\text {nd }}$, and zero otherwise. Doesn't Know / Will Vote Blank is a dummy variable that equals 1 if the respondent declares she/he will vote blank or does not know who will vote for in the ballotage of November $22^{\text {nd }}$, and zero otherwise. Propaganda is a dummy variable that equals 1 if the respondent was shown a part of an episode of 6, 7, 8, and zero otherwise. In columns (4), (5) and (6) Age, Gender, Household Head, Years of Education, HH - Years of Education, Buenos Aires City, Greater Buenos Aires, Messi is Better, Poor Don't Make Effort and Penalty are included as controls. * Significant at $10 \% ; * *$ significant at $5 \%$. 
Table 4: Effects of Propaganda and Antidotes

(1)

\begin{tabular}{|c|c|c|c|c|c|c|}
\hline & $\overline{(1)}$ & 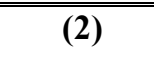 & (3) & (4) & $\overline{~(5)}$ & (6) \\
\hline Variables & $\begin{array}{l}\text { Will Vote } \\
\text { Macri }\end{array}$ & $\begin{array}{c}\text { Will Vote } \\
\text { Scioli }\end{array}$ & $\begin{array}{c}\text { Doesn't Know } \\
\text { / Will Vote } \\
\text { Blank }\end{array}$ & $\begin{array}{c}\text { Will Vote } \\
\text { Macri }\end{array}$ & $\begin{array}{l}\text { Will Vote } \\
\text { Scioli }\end{array}$ & $\begin{array}{c}\text { Doesn't Know } \\
\text { / Will Vote } \\
\text { Blank }\end{array}$ \\
\hline Propaganda & $\begin{array}{l}-0.062^{*} \\
(0.034)\end{array}$ & $\begin{array}{c}0.025 \\
(0.028)\end{array}$ & $\begin{array}{c}0.037 \\
(0.031)\end{array}$ & $\begin{array}{l}-0.062^{*} \\
(0.034)\end{array}$ & $\begin{array}{c}0.025 \\
(0.028)\end{array}$ & $\begin{array}{c}0.037 \\
(0.031)\end{array}$ \\
\hline Antidotes & $\begin{array}{l}-0.005 \\
(0.034)\end{array}$ & $\begin{array}{l}-0.011 \\
(0.028)\end{array}$ & $\begin{array}{c}0.016 \\
(0.031)\end{array}$ & & & \\
\hline Antidote 1 & & & & $\begin{array}{c}0.024 \\
(0.048)\end{array}$ & $\begin{array}{l}-0.042 \\
(0.039)\end{array}$ & $\begin{array}{c}0.018 \\
(0.044)\end{array}$ \\
\hline Antidote 2 & & & & $\begin{array}{l}-0.035 \\
(0.048)\end{array}$ & $\begin{array}{l}-0.021 \\
(0.039)\end{array}$ & $\begin{array}{c}0.056 \\
(0.044)\end{array}$ \\
\hline Antidote 3 & & & & $\begin{array}{c}-0.004 \\
(0.048)\end{array}$ & $\begin{array}{c}0.029 \\
(0.039)\end{array}$ & $\begin{array}{l}-0.025 \\
(0.044)\end{array}$ \\
\hline Constant & $\begin{array}{c}0.060 \\
(0.125)\end{array}$ & $\begin{array}{c}0.494 \\
(0.101)\end{array}$ & $\begin{array}{c}0.446 \\
(0.113)\end{array}$ & $\begin{array}{c}0.060 \\
(0.125)\end{array}$ & $\begin{array}{c}0.496 \\
(0.101)\end{array}$ & $\begin{array}{c}0.444 \\
(0.112)\end{array}$ \\
\hline Observations & 1,202 & 1,202 & 1,202 & 1,202 & 1,202 & 1,202 \\
\hline
\end{tabular}

Notes: Seemingly unrelated regression (SUR) estimates. Standard errors in parentheses. Will Vote Macri is a dummy variable that equals 1 if the respondent declares she/he will vote for Macri in the ballotage of November $22^{\text {nd }}$, and zero otherwise. Will Vote Scioli is a dummy variable that equals 1 if the respondent declares she/he will vote for Scioli in the ballotage of November $22^{\text {nd }}$, and zero otherwise. Doesn't Know / Will Vote Blank is a dummy variable that equals 1 if the respondent declares she/he will vote blank or does not know who will vote for in the ballotage of November $22^{\text {nd }}$, and zero otherwise. Propaganda is a dummy variable that equals 1 if the respondent was shown a part of an episode of $6,7,8$, and zero otherwise. Antidotes is a dummy variable that equals 1 if the respondent was shown any type of counter video, and zero otherwise. Antidote 1 is a dummy variable that equals 1 if the respondent was shown a video of Macri describing his proposals, and zero otherwise. Antidote 2 is a dummy variable that equals 1 if the respondent was shown a video of Macri describing the measures that he was not willing to undertake, and zero otherwise. Antidote 3 is a dummy variable that equals 1 if the respondent was shown an interview of candidate Scioli defending the candidacy of thenpresident Carlos Menem and the privatization of state-owned oil company YPF in the late 90's, and zero otherwise. All regressions include Age, Gender, Household Head, Years of Education, HH - Years of Education, Buenos Aires City, Greater Buenos Aires, Messi is Better, Poor Don't Make Effort and Penalty as controls. * Significant at 10\%. 
Table 5: Effects of Propaganda on Women and Men

\begin{tabular}{|c|c|c|c|c|c|c|c|c|c|c|c|c|}
\hline & \multicolumn{6}{|c|}{ Effects of Propaganda on Women } & \multicolumn{6}{|c|}{ Effects of Propaganda on Men } \\
\hline & (1) & (2) & (3) & (4) & (5) & (6) & (7) & (8) & (9) & (10) & (11) & (12) \\
\hline Variables & $\begin{array}{l}\text { Will Vote } \\
\text { Macri }\end{array}$ & $\begin{array}{l}\text { Will Vote } \\
\text { Scioli }\end{array}$ & $\begin{array}{c}\text { Doesn't } \\
\text { Know / Will } \\
\text { Vote Blank } \\
\end{array}$ & $\begin{array}{c}\text { Will Vote } \\
\text { Macri }\end{array}$ & $\begin{array}{l}\text { Will Vote } \\
\text { Scioli }\end{array}$ & $\begin{array}{c}\text { Doesn't } \\
\text { Know / Will } \\
\text { Vote Blank } \\
\end{array}$ & $\begin{array}{l}\text { Will Vote } \\
\text { Macri }\end{array}$ & $\begin{array}{l}\text { Will Vote } \\
\text { Scioli }\end{array}$ & $\begin{array}{c}\text { Doesn't } \\
\text { Know / Will } \\
\text { Vote Blank } \\
\end{array}$ & $\begin{array}{l}\text { Will Vote } \\
\text { Macri }\end{array}$ & $\begin{array}{l}\text { Will Vote } \\
\text { Scioli }\end{array}$ & $\begin{array}{c}\text { Doesn't } \\
\text { Know / Will } \\
\text { Vote Blank } \\
\end{array}$ \\
\hline Propaganda & $\begin{array}{c}-0.118^{* * *} \\
(0.040)\end{array}$ & $\begin{array}{c}0.042 \\
(0.032)\end{array}$ & $\begin{array}{c}0.076^{* *} \\
(0.037)\end{array}$ & $\begin{array}{c}-0.101 * * \\
(0.045)\end{array}$ & $\begin{array}{c}0.024 \\
(0.036)\end{array}$ & $\begin{array}{l}0.077^{*} \\
(0.043)\end{array}$ & $\begin{array}{l}-0.005 \\
(0.044)\end{array}$ & $\begin{array}{l}-0.008 \\
(0.036)\end{array}$ & $\begin{array}{c}0.013 \\
(0.038)\end{array}$ & $\begin{array}{l}-0.012 \\
(0.052)\end{array}$ & $\begin{array}{c}0.024 \\
(0.043)\end{array}$ & $\begin{array}{c}-0.012 \\
(0.045)\end{array}$ \\
\hline Antidotes & & & & $\begin{array}{l}-0.037 \\
(0.047)\end{array}$ & $\begin{array}{c}0.038 \\
(0.037)\end{array}$ & $\begin{array}{l}-0.001 \\
(0.044)\end{array}$ & & & & $\begin{array}{c}0.012 \\
(0.050)\end{array}$ & $\begin{array}{l}-0.058 \\
(0.041)\end{array}$ & $\begin{array}{c}0.045 \\
(0.043)\end{array}$ \\
\hline Constant & $\begin{array}{c}0.007 \\
(0.170)\end{array}$ & $\begin{array}{c}0.411 \\
(0.135)\end{array}$ & $\begin{array}{c}0.582 \\
(0.159)\end{array}$ & $\begin{array}{l}-0.000 \\
(0.170)\end{array}$ & $\begin{array}{c}0.419 \\
(0.135)\end{array}$ & $\begin{array}{c}0.581 \\
(0.159)\end{array}$ & $\begin{array}{c}0.118 \\
(0.192)\end{array}$ & $\begin{array}{c}0.680 \\
(0.157)\end{array}$ & $\begin{array}{c}0.202 \\
(0.165)\end{array}$ & $\begin{array}{c}0.118 \\
(0.192)\end{array}$ & $\begin{array}{c}0.681 \\
(0.157)\end{array}$ & $\begin{array}{c}0.201 \\
(0.164)\end{array}$ \\
\hline Observations & 656 & 656 & 656 & 656 & 656 & 656 & 546 & 546 & 546 & 546 & 546 & 546 \\
\hline
\end{tabular}

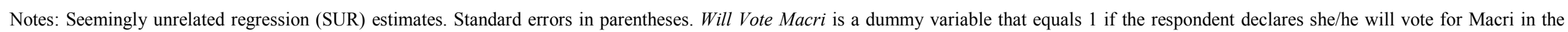

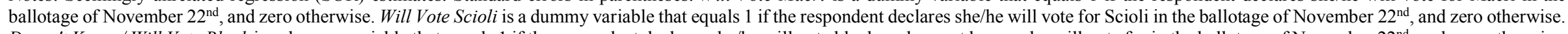

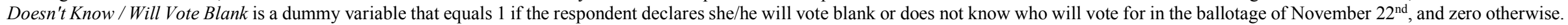

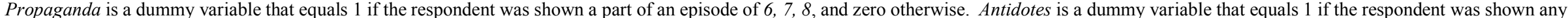

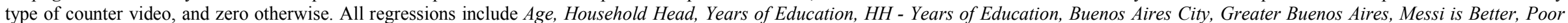
Don't Make Effort and Penalty as controls. * Significant at 10\%; ** significant at 5\%; *** significant at $1 \%$. 
Table 6: Agreement on whether "Macri wants to lower wages" and Opinion on Macri

\begin{tabular}{|c|c|c|c|c|c|c|}
\hline \multirow{3}{*}{ Variables } & \multicolumn{3}{|c|}{ Macri wants to lower wages } & \multicolumn{3}{|c|}{ Opinion on Macri } \\
\hline & (1) & (2) & (3) & (4) & (5) & $(6)$ \\
\hline & Total & Women & Men & Total & Women & Men \\
\hline Propaganda & $\begin{array}{c}0.015 \\
(0.027)\end{array}$ & $\begin{array}{l}0.062 * \\
(0.036)\end{array}$ & $\begin{array}{c}-0.044 \\
(0.042)\end{array}$ & $\begin{array}{l}-0.089 \\
(0.158)\end{array}$ & $\begin{array}{c}-0.385 * \\
(0.211)\end{array}$ & $\begin{array}{c}0.225 \\
(0.237)\end{array}$ \\
\hline Constant & $\begin{array}{c}0.661 \\
(0.114)\end{array}$ & $\begin{array}{c}0.492 \\
(0.151)\end{array}$ & $\begin{array}{c}0.911 \\
(0.177)\end{array}$ & $\begin{array}{c}4.238 \\
(0.690)\end{array}$ & $\begin{array}{c}4.271 \\
(0.929)\end{array}$ & $\begin{array}{c}3.962 \\
(1.066)\end{array}$ \\
\hline Observations & 1,202 & 656 & 546 & 1,202 & 656 & 546 \\
\hline
\end{tabular}

Notes: OLS estimates. Robust standard errors in parentheses. Macri wants to lower wages is a dummy variable that equals 1 if the respondent believes Macri wants to lower wages, and zero otherwise. Opinion on Macri is the respondent's grade from 1 to 10 of her/his opinion of Macri as a politician. Propaganda is a dummy variable that equals 1 if the respondent was shown a part of an episode of 6, 7, 8, and zero otherwise. Age, Household Head, Years of Education, HH - Years of Education, Buenos Aires City, Greater Buenos Aires, Messi is Better, Poor Don't Make Effort and Penalty are included as controls. In columns (1) and (4), Gender is also included as control. * Significant at $10 \%$. 
Table 7: Effects of Propaganda - Original Sample (inputting attrited participants)

\begin{tabular}{|c|c|c|c|c|c|c|c|c|c|}
\hline & \multicolumn{3}{|c|}{ Total } & \multicolumn{3}{|c|}{ Women } & \multicolumn{3}{|c|}{ Men } \\
\hline & (1) & (2) & (3) & (4) & (5) & (6) & (7) & (8) & (9) \\
\hline Variables & $\begin{array}{c}\text { Will Vote } \\
\text { Macri }\end{array}$ & $\begin{array}{l}\text { Will Vote } \\
\text { Scioli }\end{array}$ & $\begin{array}{c}\text { Doesn't Know } \\
\text { / Will Vote } \\
\text { Blank }\end{array}$ & $\begin{array}{l}\text { Will Vote } \\
\text { Macri }\end{array}$ & $\begin{array}{l}\text { Will Vote } \\
\text { Scioli }\end{array}$ & $\begin{array}{c}\text { Doesn't Know } \\
\text { / Will Vote } \\
\text { Blank }\end{array}$ & $\begin{array}{l}\text { Will Vote } \\
\text { Macri }\end{array}$ & $\begin{array}{l}\text { Will Vote } \\
\text { Scioli }\end{array}$ & $\begin{array}{c}\text { Doesn't Know } \\
\text { / Will Vote } \\
\text { Blank }\end{array}$ \\
\hline Propaganda & $\begin{array}{c}-0.054 * \\
(0.029)\end{array}$ & $\begin{array}{c}0.015 \\
(0.023)\end{array}$ & $\begin{array}{c}0.038 \\
(0.024)\end{array}$ & $\begin{array}{c}-0.093 * * \\
(0.039)\end{array}$ & $\begin{array}{c}0.032 \\
(0.030)\end{array}$ & $\begin{array}{l}0.061 * \\
(0.037)\end{array}$ & $\begin{array}{c}0.000 \\
(0.044)\end{array}$ & $\begin{array}{l}-0.011 \\
(0.035)\end{array}$ & $\begin{array}{c}0.010 \\
(0.037)\end{array}$ \\
\hline Constant & $\begin{array}{c}0.036 \\
(0.116)\end{array}$ & $\begin{array}{c}0.494 \\
(0.099)\end{array}$ & $\begin{array}{c}0.470 \\
(0.106)\end{array}$ & $\begin{array}{c}-0.030 \\
(0.170)\end{array}$ & $\begin{array}{c}0.439 \\
(0.140)\end{array}$ & $\begin{array}{c}0.590 \\
(0.154)\end{array}$ & $\begin{array}{c}0.063 \\
(0.185)\end{array}$ & $\begin{array}{c}0.659 \\
(0.148)\end{array}$ & $\begin{array}{c}0.278 \\
(0.159)\end{array}$ \\
\hline Observations & 1,271 & 1,271 & 1,271 & 698 & 698 & 698 & 573 & 573 & 573 \\
\hline
\end{tabular}

Notes: Seemingly unrelated regression (SUR) estimates. Will Vote Macri is a dummy variable that equals 1 if the respondent will vote Macri in the ballotage of November $22^{\text {nd }}$, and zero otherwise. Will Vote Scioli is a dummy variable that equals 1 if the respondent will vote Scioli in the ballotage of November $22^{\text {nd }}$, and zero otherwise. Doesn't Know / Will Vote Blank is a dummy variable that equals 1 if the respondent does not know who will vote or will vote blank in the ballotage of November $22^{\text {nd }}$, and zero otherwise. The 45 participants ( 28 women and 17 men) in the treatment group who did not declare their ballotage vote intention are imputed to Macri. The ballotage vote intentions of the 16 attrited participants (9 women and 7 men) in the control group are forecasted using the coefficients obtained from a multinomial Logit model estimated on all the control group observations (columns 1 to 3), the female control observations (columns 4 to 6), and the male control observations (columns 7 to 9). Bootstrapped standard errors using 1000 replications in parentheses. Propaganda is a dummy variable that equals 1 if the respondent was shown a part of an episode of 6, 7, 8, and zero otherwise. Age, Household Head, Years of Education, HH - Years of Education, Buenos Aires City, Greater Buenos Aires, Messi is Better, Poor don't make Effort and Penalty are included as controls in all columns. Gender is included as control in columns (1), (2) and (3). * Significant at 10\%; ** significant at 5\%. 
Table 8: Effects of Propaganda Controlling for First-Round Vote

\begin{tabular}{|c|c|c|c|c|c|c|c|c|c|}
\hline & \multicolumn{3}{|c|}{ Total } & \multicolumn{3}{|c|}{ Women } & \multicolumn{3}{|c|}{ Men } \\
\hline & (1) & (2) & (3) & (4) & (5) & (6) & (7) & (8) & (9) \\
\hline Variables & $\begin{array}{l}\text { Will Vote } \\
\text { Macri }\end{array}$ & $\begin{array}{l}\text { Will Vote } \\
\text { Scioli }\end{array}$ & $\begin{array}{c}\text { Doesn't Know / } \\
\text { Will Vote } \\
\text { Blank }\end{array}$ & $\begin{array}{l}\text { Will Vote } \\
\text { Macri }\end{array}$ & $\begin{array}{l}\text { Will Vote } \\
\text { Scioli }\end{array}$ & $\begin{array}{c}\text { Doesn't Know / } \\
\text { Will Vote } \\
\text { Blank } \\
\end{array}$ & $\begin{array}{l}\text { Will Vote } \\
\text { Macri }\end{array}$ & $\begin{array}{l}\text { Will Vote } \\
\text { Scioli }\end{array}$ & $\begin{array}{c}\text { Doesn't Know / } \\
\text { Will Vote } \\
\text { Blank }\end{array}$ \\
\hline Propaganda & $\begin{array}{l}-0.039 * \\
(0.020)\end{array}$ & $\begin{array}{c}0.019 \\
(0.016)\end{array}$ & $\begin{array}{c}0.020 \\
(0.022)\end{array}$ & $\begin{array}{c}-0.079 * * * \\
(0.027)\end{array}$ & $\begin{array}{c}0.031 \\
(0.021)\end{array}$ & $\begin{array}{c}0.048 \\
(0.030)\end{array}$ & $\begin{array}{c}0.011 \\
(0.031)\end{array}$ & $\begin{array}{c}-0.000 \\
(0.024)\end{array}$ & $\begin{array}{l}-0.011 \\
(0.032)\end{array}$ \\
\hline Voted Macri & $\begin{array}{c}0.563 * * * \\
(0.049)\end{array}$ & $\begin{array}{c}-0.098 * * \\
(0.039)\end{array}$ & $\begin{array}{c}-0.465^{* * *} \\
(0.053)\end{array}$ & $\begin{array}{c}0.595 * * * \\
(0.061)\end{array}$ & $\begin{array}{l}-0.060 \\
(0.047)\end{array}$ & $\begin{array}{c}-0.535 * * * \\
(0.068)\end{array}$ & $\begin{array}{c}0.519 * * * \\
(0.083)\end{array}$ & $\begin{array}{c}-0.185^{* * *} \\
(0.065)\end{array}$ & $\begin{array}{c}-0.334 * * * \\
(0.085)\end{array}$ \\
\hline Voted Scioli & $\begin{array}{c}-0.304^{* * *} \\
(0.053)\end{array}$ & $\begin{array}{c}0.740 * * * \\
(0.041)\end{array}$ & $\begin{array}{c}-0.437 * * * \\
(0.057)\end{array}$ & $\begin{array}{c}-0.275^{* * *} \\
(0.065)\end{array}$ & $\begin{array}{c}0.777 * * * \\
(0.050)\end{array}$ & $\begin{array}{c}-0.502 * * * \\
(0.072)\end{array}$ & $\begin{array}{c}-0.338^{* * *} \\
(0.089)\end{array}$ & $\begin{array}{c}0.650 * * * \\
(0.069)\end{array}$ & $\begin{array}{c}-0.312 * * * \\
(0.091)\end{array}$ \\
\hline Voted Massa & $\begin{array}{c}0.166^{* * *} \\
(0.054)\end{array}$ & $\begin{array}{c}0.032 \\
(0.043)\end{array}$ & $\begin{array}{c}-0.198^{* * *} \\
(0.059)\end{array}$ & $\begin{array}{c}0.212 * * * \\
(0.068)\end{array}$ & $\begin{array}{c}0.106^{* *} \\
(0.053)\end{array}$ & $\begin{array}{c}-0.318^{* * * *} \\
(0.076)\end{array}$ & $\begin{array}{c}0.109 \\
(0.090)\end{array}$ & $\begin{array}{l}-0.080 \\
(0.070)\end{array}$ & $\begin{array}{l}-0.029 \\
(0.092)\end{array}$ \\
\hline Voted others & $\begin{array}{c}-0.154 * * * \\
(0.051)\end{array}$ & $\begin{array}{c}0.021 \\
(0.040)\end{array}$ & $\begin{array}{c}0.134 * * \\
(0.055)\end{array}$ & $\begin{array}{c}-0.150 * * \\
(0.063)\end{array}$ & $\begin{array}{c}0.034 \\
(0.049)\end{array}$ & $\begin{array}{l}0.117^{*} \\
(0.071)\end{array}$ & $\begin{array}{l}-0.168 * \\
(0.086)\end{array}$ & $\begin{array}{l}-0.034 \\
(0.067)\end{array}$ & $\begin{array}{l}0.202 * * \\
(0.088)\end{array}$ \\
\hline Constant & $\begin{array}{c}0.277 \\
(0.097)\end{array}$ & $\begin{array}{l}-0.007 \\
(0.076)\end{array}$ & $\begin{array}{c}0.730 \\
(0.105)\end{array}$ & $\begin{array}{c}0.264 \\
(0.125)\end{array}$ & $\begin{array}{l}-0.174 \\
(0.097)\end{array}$ & $\begin{array}{c}0.910 \\
(0.140)\end{array}$ & $\begin{array}{c}0.297 \\
(0.160)\end{array}$ & $\begin{array}{c}0.289 \\
(0.125)\end{array}$ & $\begin{array}{c}0.414 \\
(0.163)\end{array}$ \\
\hline Observations & 1,202 & 1,202 & 1,202 & 656 & 656 & 656 & 546 & 546 & 546 \\
\hline
\end{tabular}

Notes: Seemingly unrelated regression (SUR) estimates. Standard errors in parentheses. Will Vote Macri is a dummy variable that equals 1 if the respondent declares she/he will vote for Macri in the ballotage of November $22^{\text {nd }}$, and zero otherwise. Will Vote Scioli is a dummy variable that equals 1 if the respondent declares she/he will vote for Scioli in the ballotage of November $22^{\text {nd }}$, and zero otherwise. Doesn't Know / Will Vote Blank is a dummy variable that equals 1 if the respondent declares she/he will vote blank or does not know who will vote for in the ballotage of November $22^{\text {nd }}$, and zero otherwise. Propaganda is a dummy variable that equals 1 if the respondent was shown a part of an episode of $6,7,8$, and zero otherwise. Voted Macri is a dummy variable that equals 1 if the respondent voted for Macri in the general election of October $25^{\text {th }}$, and zero otherwise. Voted Scioli is a dummy variable that equals 1 if the respondent voted for Scioli in the general election of October $25^{\text {th }}$, and zero otherwise. Voted Massa is a dummy variable that equals 1 if the respondent voted for Massa in the general election of October $25^{\text {th }}$, and zero otherwise. Voted others is a dummy variable that equals 1 if the respondent voted any other candidate in the general election of October $25^{\text {th }}$, and zero otherwise. Age, Household Head, Years of Education, HH - Years of Education, Buenos Aires City, Greater Buenos Aires, Messi is Better, Poor Don't Make Effort and Penalty are included as controls. In columns (1) to (3), Gender is also included as control * Significant at $10 \%$;* significant at $5 \%$; *** significant at $1 \%$. 


\section{Online Appendix}

\section{Online Appendix 1: Wonderpanel Survey}

1. Please indicate your gender:

- Male

- Female

2. What is the highest education level that you have achieved?

$\circ$ Less than primary level complete

- Primary level complete

- Secondary Incomplete

- Secondary Complete

- Tertiary Incomplete

- Tertiary Complete

- University Incomplete

- University Complete

- Postgraduate / Masters / Doctorate

3. Who is the household head in your home? (The highest-earning person in your household)

○ $\mathrm{Me}$

- Another Person

4. What is the highest education level that the head of household achieved?

- Less than primary level complete

- Primary level complete

- Secondary Incomplete

- Secondary Complete

- Tertiary Incomplete

- Tertiary Complete

- University Incomplete

- Postgraduate / Masters / Doctorate

5. What is your place of residence?

Capital Federal

Provincia de Bs As - GBA Norte

Provincia de Bs As - GBA Oeste

Provincia de Bs As - GBA Sur

Provincia de Buenos Aires - Resto

Córdoba

Mendoza

Tucumán

Santa Fe

Another Country (Specify)
San Luis

Entre Rios

Misiones

Formosa

Chaco

Neuquén

Rio Negro

Chubut

Santa Cruz
San Juan

Santiago del Estero

Jujuy

La Rioja

Salta

Corrientes

Tierra del Fuego

La Pampa

Catamarca

6. In which neighborhood in the City of Buenos Aires do you live?

7. In which district/neighborhood of Greater Buenos Aires do you live?

8. How old are you? 
9. In your opinion, who is a better soccer player: Messi or Maradona?

○ Messi

- Maradona

10. People have different opinions about the penalties that must be given to lawbreakers. Consider, for example, the case of a 20 -year-old man that is found guilty of robbery for the second time. This time he broke into a house and stole a computer. Which sentence do you consider more appropriate?

○ Fine

○ Prison

11. How much prison time do you think is appropriate?

12. Regarding the poor people in our country, which is the reason you consider the most important cause for them being poor?

$\circ$ They didn't have opportunities

- They weren't lucky

○ They didn't put enough effort

We ask now that you look closely at this video which lasts between 2 and 3 minutes approximately. To continue the questionnaire, it is very important that you have seen and heard correctly the complete video.

VIDEOS (either control, or any of the 4 treatments)

Please don't skip this screen until the video has come to an end. If you couldn't see and hear the complete video, click again on the video so that it plays again and you can see it completely before you continue with the questionnaire.

13. Could you see and hear the complete video correctly?

- Yes

○ No

14. Why couldn't you see or hear the video correctly?

\section{Lastly, we would like to ask you a few more questions.}

15. The current government says that Macri thinks that cost reductions are necessary, this includes salaries. Which of the statements best describes your opinion about the matter?

$\circ$ It is irrelevant now. Macri might have thought so in the past, when he was a businessman, but now he doesn't think that for the country.

- It's not clear. When he was a businessman he thought that, but then he was at Boca and the government, and he might have changed his mind.

- It's relevant today. He thinks like a businessman and therefore salary reduction is always a valid option.

16. What do you think of Mauricio Macri as a politician? From 1 to 10 , where 1 is the lowest grade and 10 is the maximum, which grade would you give him?

$\begin{array}{llllllllll}1(\min ) & 2 & 3 & 4 & 5 & 6 & 7 & 8 & 9 & 10(\max )\end{array}$


17. If we gave you $\$ 2.000$ pesos to donate to an organization, to which of these organizations would you rather donate it to?

- Soup kitchen "Los Piletones" that also receives help from Macri's government

- Soup kitchen "Sales" that also receives help from Scioli's government

18. Who will you vote in the ballotage of November 22nd?

○ Daniel Scioli

- Mauricio Macri

- Blank

- I don't know

19. You think that the government of Nestor Kirchner (2003-2007) was...

○ Very good

- Good

- Regular

○ Bad

○ Very bad

20. In the first round of presidential elections of the past October $25^{\text {th }}$ who did you vote for?

- Daniel Scioli

- Mauricio Macri

- Sergio Massa

- Nicolás Del Caño

- Margarita Stolbizer

○ Adolfo Rodriguez Saá

O Blank

- I don't know/remember

- I didn't vote

21. How many people live in your home including yourself?

$\begin{array}{lllllllllll}1 & 2 & 3 & 4 & 5 & 6 & 7 & 8 & 9 & 10 & \text { More than } 10\end{array}$

22. And how many of your household members contribute with their income to cover house expenses?

$\begin{array}{llllll}1 & 2 & 3 & 4 & 5 & \text { More than } 5\end{array}$

Thank you for your answers. We only have a few questions about the household head in your home, who is the highest-earning member of your household; it can be you or another person. The answers are confidential and the only objective is to classify you for statistical purposes.

23. Currently, does the household head in your house have an activity or a job?

○ Yes

○ No

24. The household head ... (Mark the ones that apply)

- Has some rents, investments or businesses in which she/he doesn't work

- Has a study or research scholarship

- Receives money from family or relatives that don't live in the same house

$\circ$ Has a pension

$\circ$ Is retired from an activity or a job

- Is unemployed

- Has a social plan

25. Which of the options best describes where and how the household head works? (If he/she currently doesn't work, refer the answer to her/his last job) 
○ Owner or partner of a company/business/professional study/store

- In a social institution or public entity

- In a company, factory, business, professional study or store

- In a public unit, agency or bank

- Works on her/his own, without employees

- Works for a person who gives her/him work

$\circ$ Works in family homes

26. How many people work in the place where the household head works? (If he/she currently doesn't work, refer the answer to her/his last job)

- Up to 5 people

- Between 6 and 40

- Between 41 and 200

○ More than 200 people

27. Which hierarchy does the household head have? (If he/she currently doesn't work, refer the answer to her/his last job)

- Executive/Manager

- Boss

- Employee (no hierarchy or people in charge)

28. What knowledge or qualifications does the household head need in order to do her/his job? (If he/she currently doesn't work, refer the answer to her/his last job)

- Professional

- Technician

- Operator

- Not qualified

29. Does the household head currently have some type of medical coverage?

- Yes, health insurance.

- Yes, labor union coverage

- Yes, prepaid medicine service

o No

Thank you for participation!

Press the End button to record your answers. 


\section{Online Appendix 2: Descriptions of the Videos}

Description of the Videos (abridged):

Control: The control video explaining the electoral rules.

Treatment 1: The video of an "ad" for the show 6, 7,8 showing "similarities" between Macri's economic plan and that of the 1970's Dictatorship.

Treatment 2: The same as in treatment 1 followed by a video of an ad of the Macri campaign showing candidate Mauricio Macri explaining his proposals.

Treatment 3: The same as in treatment 1 followed by a video of an ad of the Macri campaign showing candidate Mauricio Macri explaining what he will not do.

Treatment 4: The same as in treatment 1 followed by a video of an ad of the Macri campaign showing candidate Daniel Scioli defending the 1990's neoliberal government.

Description of the Videos (full):

\section{Video 1: Control}

(an informative video of the election process)

Next Sunday, Argentinians 18 or older are obliged to vote for the next president along with other positions. Those aged 16 or 17 also have the right to vote, and even though putting your vote into a ballot box might seem an easy task, in Argentina it isn't. Let me tell you why. Only one ticket includes the whole list of candidates running for the positions to be elected, and this would sometimes mean the ballot can even be up to 40 inches long!

This coming Sunday, the president and the vice president will be elected. In some provinces, a governor will also be chosen. In Congress, some members of the House of Representatives and the Senate will also end their terms. Also, the Argentine members of the Parlasur will be chosen; the Parlasur is the Mercosur Parliament, with headquarters in Montevideo. As if this wasn't enough, some cities also choose Mayors and City Councilmen.

But this is the really complex part of this process: an Argentine voter can choose, if they want, a president from one party, a governor from another party, and a mayor from a third party and members of the Parlasur from another party. Let's imagine that a voter in the province of Buenos Aires wants to vote Frente deIzquierda's presidential candidate, Cambiemos' gubernatorial candidate, representatives from progressive parties and leave the rest in blank. They would have to cut them all up, put these three pieces together in an envelope and discard the rest. It's such a complex system that a city in Argentina even chose to design an interactive tutorial to explain how to vote. This way of voting has been harshly criticized by those who think that it is prone to mistake and fraud. Nevertheless, so far there hasn't been an agreement to resort to electronic voting or any other ways of voting. This is why, to this day, the Argentine people will still have to carry scissors to polling stations.

\section{Video 2: Main Propaganda Video}

(an "ad" for the pro-Kirchner show 6, 7, 8, with edited excerpts of statements by Macri and other politicians, some of them quite old, followed by "similar" statements by Martinez de Hoz, the Minister of Economy of the 1970's Dictatorship)

[Voice-Over] Striking similarities; Macri's economic plan is the same as the dictatorship's. Let's go back to 1980, let's listen to the economic plan developed by Matinez de Hoz during his dictatorship. Let's see if it 
rings a bell with the current proposal. Jose A. Martinez de Hoz -1980- The Dictatorship's Minister of Economy.

[Martinez de Hoz] I would like to stress some points I think are paramount to measure the extent of the transformation we have brought about. In the first place, the freedom to conduct foreign currency transactions and the elimination of foreign exchange controls.

[Macri] If you are elected President, will we have a free foreign exchange market?

Well it's the ABC. We'll see what the market flow indicates, in terms of what our equilibrium exchange rate should be.

[Martinez de Hoz] The elimination of foreign exchange controls.

[Macri] The "CEPO" [control of foreign currency] will end on December $11^{\text {th }}$.

[Martinez de Hoz] Second, the freedom to export through the elimination of export taxes and restrictions.

[Macri] Zero export restrictions. Zero taxes.

[Martinez de Hoz] Third, the freedom to import, and the elimination of bans, quotas or licenses.

[Journalist] Will imports be free in Argentina?

[Rodriguez Larreta - Macri's former Chief of Staff] We have to reopen them, of course.

[Journalist] Do we have to open [the economy]?

[Rodriguez Larreta] Of course.

[Martinez de Hoz] The freedom to import, freedom to receive foreign investments.

[Macri] Zero export taxes and restrictions for all regional economies. That will lead to an investment boom.

[Martinez de Hoz] Freedom for foreign investments. Fifth, the elimination of political fees on public services.

[Journalist] Today, the majority of public services subsidies, namely, gas, or electricity would affect the entire middle class, who constitute the majority of the people, not just those who earn minimum wage.

[Michetti - Macri's vice presidential candidate]

But wait. There is a part of the middle class who are paying ridiculously low electricity and gas bills. We cannot afford electricity, gas and even transportation at the prices we are paying.

[Martinez de Hoz] The elimination of political taxes? Fees? on public services. Sixth, the freedom to contract labor upon the minimum wages established by the State.

[Macri] What we have to do is lower costs. And wages are an additional cost.

Ad: [Men] Oh, the roof, please!! 
[Men] Oh, that's better.

[V.O.] The floor will immediately start rising.

[Men] The floor is shaking.

[V.O.] This means more inflation. Everything would go back to the way it used to be.

[Men] Oh, men, the floor.

[V.O.] So, what has the government done with these new measures?

[Men] They're lowering the floor. That's the secret.

[Macri] What we have to do is lower costs. And wages are an additional cost.

[V.O.] This is the economic chapter of Macri's economists. It's been 36 years since Martinez de Hoz's speech, 36 years. Incredible.

Video 3: Main Propaganda Plus the "Positive Antidote"

(Video 2 followed by an ad featuring Macri explaining his proposals)

[Macri] I propose a universal basic income. And that we agree to start revolutionizing the quality of public education. And another revolution in terms of infrastructure investment plans. One of our cornerstones has to be housing conditions. This is our task: turning this country into a place where everyone has room for progress, where we all feel that we are better off every day. I propose "zero poverty" in Argentina.

\section{Video 4: Main Propaganda Plus the "Defensive Antidote"}

(Video 2 followed by an ad featuring Macri explaining what he is not going to do).

[Macri] To get to know a person, it is equally important to know what he does, as what he is not willing to do. That is why I'm going to tell you what I am NOT going to do. I will not look for enemies, nor pointless quarrels. I will not speak without listening. I will not try to perpetuate myself in power. I will not persecute those who think differently. I will not lie with INDEC's reports, inflation, or anything at all. I will not take away anyone's social assistance away. I will not change the things that were done right. And the most important thing is that I will not let you down nor any of the Argentinians. Because the only way to create the country that we want is by doing so together.

\section{Video 5: Main Propaganda Plus the "Attack Antidote”}

(Video 2 followed by an old interview of Scioli defending the privatizations at Longobardi's TV show).

[Majul] There is also an interview made by Marcelo Longobardi [journalist] in which the then national representative Scioli pronounces himself in favor of privatizations and emphatically asks to modify the Constitution so that Menem can be reelected for the third time. Yes, Scioli; Scioli, himself. Look!

[Longobardi] ... the views of Menem and the justicialismo on privatizing YPF. I heard Menem in the elections -

[Scioli] Interrupts Longobardi. I think it was in Menem's thoughts, but historically also in Peron's thoughts, when he said that we could privatize or nationalize companies according to the international circumstances. 
President Menem brought this thinking to the present. He stood up to the challenge of putting Argentina back in the world and Menem's privatization is welcome. Because it brought huge losses, it did not pay taxes. I am convinced that the next President will be someone who can guarantee the continuation of this, and it will be a President from the justicialismo. Personally, I would like this person to be Menem; if it is not Menem, it will be another candidate but one from justicialismo. The growth of the country from 1995 to the present, the level of investments, lower unemployment rates... Sure, maybe we haven't done as much as we wished as Argentinians, but I am convinced that the hardest part is now behind us, and we have to look forward with faith and optimism. 
Online Appendix Table A1: Pre-treatment Characteristics - Women - Original Sample (including participants with incomplete answers)

\begin{tabular}{lcccccc}
\hline \hline Variables & $\begin{array}{c}(1) \\
\text { Control }\end{array}$ & $\begin{array}{c}(2) \\
\text { Propaganda }\end{array}$ & $\begin{array}{c}(3) \\
\text { Propaganda } \\
\text { only }\end{array}$ & $\begin{array}{c}(4) \\
\text { Propaganda } \\
\text { + Antidote1 }\end{array}$ & $\begin{array}{c}(5) \\
\text { Propaganda } \\
\text { + Antidote2 }\end{array}$ & $\begin{array}{c}\text { Propaganda } \\
\text { + Antidote3 }\end{array}$ \\
\hline Age & 39.426 & 0.540 & 0.149 & 1.858 & 0.145 & 0.960 \\
Household Head & $(10.015)$ & $(0.794)$ & $(0.882)$ & $(1.434)$ & $(1.150)$ & $(1.396)$ \\
& 0.417 & 0.008 & 0.051 & -0.080 & -0.032 & -0.017 \\
Years of Education & $(0.494)$ & $(0.040)$ & $(0.045)$ & $(0.064)$ & $(0.067)$ & $(0.067)$ \\
& 16.152 & 0.047 & -0.046 & 0.199 & 0.176 & 0.091 \\
HH - Years of Education & $(2.087)$ & $(0.172)$ & $(0.197)$ & $(0.316)$ & $(0.282)$ & $(0.296)$ \\
& 15.852 & 0.024 & -0.195 & 0.391 & 0.319 & 0.134 \\
Buenos Aires City & $(2.541)$ & $(0.211)$ & $(0.249)$ & $(0.376)$ & $(0.314)$ & $(0.344)$ \\
& 0.409 & -0.003 & 0.017 & -0.057 & -0.009 & -0.009 \\
Greater Buenos Aires & $(0.493)$ & $(0.040)$ & $(0.045)$ & $(0.065)$ & $(0.067)$ & $(0.067)$ \\
& 0.339 & 0.022 & 0.027 & 0.066 & -0.025 & 0.004 \\
Messi is Better & $(0.474)$ & $(0.038)$ & $(0.044)$ & $(0.065)$ & $(0.064)$ & $(0.065)$ \\
Poor don't make Effort & 0.574 & -0.029 & -0.050 & 0.007 & -0.017 & -0.002 \\
& $(0.496)$ & $(0.040)$ & $(0.045)$ & $(0.066)$ & $(0.068)$ & $(0.068)$ \\
Penalty & 0.226 & 0.007 & 0.006 & -0.010 & 0.002 & 0.031 \\
& $(0.419)$ & $(0.034)$ & $(0.038)$ & $(0.055)$ & $(0.057)$ & $(0.059)$ \\
Number of Observations & 28.722 & -1.895 & -1.178 & -2.695 & -2.579 & -2.965 \\
in each group & $(20.981)$ & $(1.670)$ & $(1.895)$ & $(2.702)$ & $(2.761)$ & $(2.740)$ \\
\hline \hline
\end{tabular}

Notes: Column (1) reports the means (and, in parentheses, their standard deviations) for the pre-treatment characteristics in the control group. The following columns provide the coefficients and robust standard errors of regressing the characteristics on a treatment dummy, considering all treatment branches together in Column (2), and then disaggregating the treatment into propaganda only and propaganda plus antidote dummies (Propaganda only, Propaganda + Antidote 1, Propaganda + Antidote 2, and Propaganda + Antidote 3) in columns (3) to (6). Age is the age of the respondent. Household Head is a dummy variable that equals one if the respondent self-defines as the head of the household, and zero otherwise. Years of Education is the education level of the respondent. HH - Years of Education is the education level of the household head. Buenos Aires City is a dummy variable that equals one if the respondent lives in Buenos Aires City. Greater Buenos Aires is a dummy variable that equals one if the respondent lives in Greater Buenos Aires. Messi is Better is a dummy variable that equals one if the respondent thinks that Lionel Messi is a better soccer player than Diego Maradona. Poor Don't Make Effort is a dummy variable that equals one if the respondent thinks that poor people are poor because they do not make effort. Penalty is the number of months that the respondent considers that a 20 -year-old man should be in prison if he is found guilty of robbery for the second time. The last row indicates the number of observations considered in each group, but all the regressions are run on the 698 female observations. 
Online Appendix Table A2: Pre-treatment Characteristics - Men - Original Sample (including participants with incomplete answers)

\begin{tabular}{lcccccc}
\hline \multirow{4}{*}{ Variables } & $(1)$ & $(2)$ & $(3)$ & $(4)$ & $(5)$ & $(6)$ \\
\cline { 2 - 6 } & Control & Propaganda & $\begin{array}{c}\text { Propaganda } \\
\text { only }\end{array}$ & $\begin{array}{c}\text { Propaganda } \\
\text { + Antidote1 }\end{array}$ & $\begin{array}{c}\text { Propaganda } \\
\text { + Antidote2 } 2\end{array}$ & $\begin{array}{c}\text { Propaganda } \\
\text { + Antidote3 }\end{array}$ \\
\hline Age & 49.337 & $-2.031^{*}$ & -2.000 & -1.740 & $-4.053^{* *}$ & -0.453 \\
Household Head & $(11.982)$ & $(1.071)$ & $(1.262)$ & $(1.727)$ & $(1.734)$ & $(1.630)$ \\
& 0.882 & 0.009 & 0.005 & 0.034 & 0.013 & -0.013 \\
Years of Education & $(0.323)$ & $(0.028)$ & $(0.034)$ & $(0.040)$ & $(0.044)$ & $(0.047)$ \\
& 16.701 & $-0.346^{*}$ & -0.330 & $-0.701^{* *}$ & -0.178 & -0.179 \\
HH - Years of Education & $(2.211)$ & $(0.197)$ & $(0.240)$ & $(0.275)$ & $(0.296)$ & $(0.318)$ \\
& 16.743 & $-0.355^{*}$ & -0.356 & $-0.660^{* *}$ & -0.072 & -0.309 \\
Buenos Aires City & $(2.257)$ & $(0.203)$ & $(0.245)$ & $(0.293)$ & $(0.292)$ & $(0.369)$ \\
& 0.439 & -0.063 & $-0.085^{*}$ & -0.064 & -0.050 & -0.018 \\
Greater Buenos Aires & $(0.498)$ & $(0.044)$ & $(0.051)$ & $(0.068)$ & $(0.070)$ & $(0.070)$ \\
& 0.283 & 0.017 & 0.020 & -0.020 & 0.045 & 0.021 \\
Messi is Better & $(0.452)$ & $(0.040)$ & $(0.048)$ & $(0.062)$ & $(0.066)$ & $(0.065)$ \\
Poor Don't Make Effort & 0.465 & -0.040 & -0.061 & 0.007 & 0.012 & -0.088 \\
& $(0.500)$ & $(0.044)$ & $(0.052)$ & $(0.070)$ & $(0.071)$ & $(0.069)$ \\
Penalty & 0.203 & 0.012 & 0.016 & 0.061 & -0.039 & 0.000 \\
& $(0.403)$ & $(0.036)$ & $(0.043)$ & $(0.060)$ & $(0.054)$ & $(0.057)$ \\
Number of Observations & 27.048 & -1.393 & -1.851 & 1.910 & -1.391 & -3.657 \\
in each group & $(22.042)$ & $(1.932)$ & $(2.262)$ & $(3.098)$ & $(2.901)$ & $(2.892)$ \\
\hline \hline
\end{tabular}

Notes: Column (1) reports the means (and, in parentheses, their standard deviations) for the pre-treatment characteristics in the control group. The following columns provide the coefficients and robust standard errors of regressing the characteristics on a treatment dummy, considering all treatment branches together in Column (2), and then disaggregating the treatment into propaganda only and propaganda plus antidote dummies (Propaganda only, Propaganda + Antidote 1, Propaganda + Antidote 2, and Propaganda + Antidote 3) in columns (3) to (6). Age is the age of the respondent. Household Head is a dummy variable that equals one if the respondent self-defines as the head of the household, and zero otherwise. Years of Education is the education level of the respondent. HH - Years of Education is the education level of the household head. Buenos Aires City is a dummy variable that equals one if the respondent lives in Buenos Aires City. Greater Buenos Aires is a dummy variable that equals one if the respondent lives in Greater Buenos Aires. Messi is Better is a dummy variable that equals one if the respondent thinks that Lionel Messi is a better soccer player than Diego Maradona. Poor Don't Make Effort is a dummy variable that equals one if the respondent thinks that poor people are poor because they do not make effort. Penalty is the number of months that the respondent considers that a 20 -year-old man should be in prison if he is found guilty of robbery for the second time. The last row indicates the number of observations considered in each group, but all the regressions are run on the 573 male observations. * Significant at $10 \%$; * significant at $5 \%$. 
Online Appendix Table A3: Pre-treatment Characteristics - Women - Main Sample

\begin{tabular}{lcccccc}
\hline Variables & $\begin{array}{c}(1) \\
\text { Control }\end{array}$ & $\begin{array}{c}(2) \\
\text { Propaganda }\end{array}$ & $\begin{array}{c}(3) \\
\text { Propaganda } \\
\text { only }\end{array}$ & $\begin{array}{c}(4) \\
\text { Propaganda } \\
\text { + Antidote1 }\end{array}$ & $\begin{array}{c}(5) \\
\text { Propaganda } \\
\text { + Antidote2 }\end{array}$ & $\begin{array}{c}(6) \\
\text { Propaganda } \\
\text { + Antidote3 }\end{array}$ \\
\hline Age & 39.527 & 0.342 & 0.134 & 0.891 & 0.055 & 0.792 \\
Household Head & $(10.065)$ & $(0.817)$ & $(0.920)$ & $(1.439)$ & $(1.188)$ & $(1.419)$ \\
Years of Education & 0.423 & -0.001 & 0.054 & $-0.109^{*}$ & -0.050 & -0.031 \\
& $(0.495)$ & $(0.041)$ & $(0.047)$ & $(0.066)$ & $(0.068)$ & $(0.068)$ \\
HH - Years of Education & 16.123 & 0.047 & -0.080 & 0.250 & 0.161 & 0.167 \\
& $(2.087)$ & $(0.178)$ & $(0.206)$ & $(0.334)$ & $(0.289)$ & $(0.297)$ \\
Buenos Aires City & 15.809 & 0.067 & -0.131 & 0.400 & 0.266 & 0.220 \\
& $(2.562)$ & $(0.219)$ & $(0.261)$ & $(0.401)$ & $(0.322)$ & $(0.348)$ \\
Greater Buenos Aires & 0.414 & -0.005 & 0.016 & -0.055 & -0.026 & -0.008 \\
& $(0.494)$ & $(0.041)$ & $(0.047)$ & $(0.068)$ & $(0.068)$ & $(0.068)$ \\
Messi is Better & 0.336 & 0.012 & 0.016 & 0.052 & -0.023 & -0.003 \\
& $(0.474)$ & $(0.039)$ & $(0.045)$ & $(0.068)$ & $(0.065)$ & $(0.065)$ \\
Poor don't make Effort & 0.582 & -0.038 & -0.058 & -0.015 & -0.015 & -0.017 \\
& $(0.494)$ & $(0.041)$ & $(0.047)$ & $(0.069)$ & $(0.069)$ & $(0.069)$ \\
Penalty & 0.223 & 0.016 & 0.013 & 0.001 & 0.016 & 0.038 \\
& $(0.417)$ & $(0.035)$ & $(0.040)$ & $(0.058)$ & $(0.059)$ & $(0.060)$ \\
Number of Observations & 29.045 & -2.458 & -1.865 & -3.165 & -3.344 & -2.915 \\
in each group & $(21.221)$ & $(1.731)$ & $(1.977)$ & $(2.836)$ & $(2.866)$ & $(2.769)$ \\
\hline \hline
\end{tabular}

Notes: Column (1) reports the means (and, in parentheses, their standard deviations) for the pre-treatment characteristics in the control group. The following columns provide the coefficients and robust standard errors of regressing the characteristics on a treatment dummy, considering all treatment branches together in Column (2), and then disaggregating the treatment into propaganda only and propaganda plus antidote dummies (Propaganda only, Propaganda + Antidote 1, Propaganda + Antidote 2, and Propaganda + Antidote 3) in columns (3) to (6). Age is the age of the respondent. Household Head is a dummy variable that equals one if the respondent self-defines as the head of the household, and zero otherwise. Years of Education is the education level of the respondent. HH - Years of Education is the education level of the household head. Buenos Aires City is a dummy variable that equals one if the respondent lives in Buenos Aires City. Greater Buenos Aires is a dummy variable that equals one if the respondent lives in Greater Buenos Aires. Messi is Better is a dummy variable that equals one if the respondent thinks that Lionel Messi is a better soccer player than Diego Maradona. Poor Don't Make Effort is a dummy variable that equals one if the respondent thinks that poor people are poor because they do not make effort. Penalty is the number of months that the respondent considers that a 20 -year-old man should be in prison if he is found guilty of robbery for the second time. The last row indicates the number of observations considered in each group, but all the regressions are run on the 656 female observations with complete answers. ${ }^{*}$ Significant at $10 \%$. 
Online Appendix Table A4: Pre-treatment Characteristics - Men - Main Sample

\begin{tabular}{lcccccc}
\hline \hline \multirow{2}{*}{ Variables } & $\begin{array}{c}(1) \\
\text { Control }\end{array}$ & $\begin{array}{c}(2) \\
\text { Propaganda }\end{array}$ & $\begin{array}{c}(3) \\
\text { Propaganda } \\
\text { only }\end{array}$ & $\begin{array}{c}(4) \\
\text { Propaganda } \\
\text { +Antidote1 }\end{array}$ & $\begin{array}{c}(5) \\
\text { Propaganda } \\
\text { + Antidote2 }\end{array}$ & $\begin{array}{c}(6) \\
\text { Propaganda } \\
+ \text { Antidote3 }\end{array}$ \\
\hline Age & 49.439 & $-2.204^{* *}$ & -2.128 & -2.334 & $-4.155^{* *}$ & -0.254 \\
Household Head & $(12.060)$ & $(1.098)$ & $(1.302)$ & $(1.758)$ & $(1.746)$ & $(1.671)$ \\
& 0.878 & 0.010 & 0.008 & 0.033 & 0.018 & -0.016 \\
Years of Education & $(0.328)$ & $(0.030)$ & $(0.035)$ & $(0.043)$ & $(0.045)$ & $(0.050)$ \\
& 16.672 & -0.314 & -0.295 & $-0.657^{* *}$ & -0.150 & -0.180 \\
HH - Years of Education & $(2.239)$ & $(0.200)$ & $(0.236)$ & $(0.284)$ & $(0.299)$ & $(0.333)$ \\
& 16.717 & -0.323 & -0.321 & $-0.612^{* *}$ & -0.045 & -0.317 \\
Buenos Aires City & $(2.287)$ & $(0.207)$ & $(0.242)$ & $(0.304)$ & $(0.296)$ & $(0.387)$ \\
& 0.439 & -0.054 & -0.080 & -0.051 & -0.051 & 0.007 \\
Greater Buenos Aires & $(0.498)$ & $(0.045)$ & $(0.053)$ & $(0.070)$ & $(0.070)$ & $(0.072)$ \\
& 0.289 & 0.001 & 0.011 & -0.035 & 0.039 & -0.027 \\
Messi is Better & $(0.455)$ & $(0.041)$ & $(0.049)$ & $(0.063)$ & $(0.067)$ & $(0.064)$ \\
Poor don't make Effort & 0.472 & -0.051 & -0.077 & 0.020 & 0.005 & $-0.118^{*}$ \\
& $(0.501)$ & $(0.045)$ & $(0.053)$ & $(0.072)$ & $(0.072)$ & $(0.070)$ \\
Penalty & 0.206 & 0.010 & 0.022 & 0.048 & -0.041 & -0.006 \\
& $(0.405)$ & $(0.037)$ & $(0.044)$ & $(0.061)$ & $(0.055)$ & $(0.058)$ \\
Number of Observations & 26.183 & -0.347 & -0.531 & 2.070 & -0.527 & -2.183 \\
\hline \hline
\end{tabular}

Notes: Column (1) reports the means (and, in parentheses, their standard deviations) for the pre-treatment characteristics in the control group. The following columns provide the coefficients and robust standard errors of regressing the characteristics on a treatment dummy, considering all treatment branches together in Column (2), and then disaggregating the treatment into propaganda only and propaganda plus antidote dummies (Propaganda only, Propaganda + Antidote 1, Propaganda + Antidote 2, and Propaganda + Antidote 3) in columns (3) to (6). Age is the age of the respondent. Household Head is a dummy variable that equals one if the respondent self-defines as the head of the household, and zero otherwise. Years of Education is the education level of the respondent. HH - Years of Education is the education level of the household head. Buenos Aires City is a dummy variable that equals one if the respondent lives in Buenos Aires City. Greater Buenos Aires is a dummy variable that equals one if the respondent lives in Greater Buenos Aires. Messi is Better is a dummy variable that equals one if the respondent thinks that Lionel Messi is a better soccer player than Diego Maradona. Poor Don't Make Effort is a dummy variable that equals one if the respondent thinks that poor people are poor because they do not make effort. Penalty is the number of months that the respondent considers that a 20 -year-old man should be in prison if he is found guilty of robbery for the second time. The last row indicates the number of observations considered in each group, but all the regressions are run on the 546 male observations with complete answers. * Significant at $10 \%$; ** significant at $5 \%$. 
Online Appendix Table A5: Donates to "Los Piletones"

\begin{tabular}{cccc}
\hline Variables & Total & Women & Men \\
\hline \hline Propaganda & $\begin{array}{c}(\mathbf{1}) \\
\text { Donates to } \\
\text { "Los Piletones" }\end{array}$ & $\begin{array}{c}\mathbf{( 3 )} \\
\text { Donates to } \\
\text { "Los Piletones" }\end{array}$ & $\begin{array}{c}\text { (5) } \\
\text { Donates to } \\
\text { "Los Piletones" }\end{array}$ \\
\hline Constant & -0.020 & -0.059 & 0.023 \\
& $(0.028)$ & $(0.037)$ & $(0.041)$ \\
Observations & 0.191 & 0.224 & 0.118 \\
& $(0.118)$ & $(0.160)$ & $(0.180)$ \\
\hline \hline
\end{tabular}

Notes: OLS estimates. Robust standard errors in parentheses. Donates to "Los Piletones" is a dummy variable that equals 1 if the respondent chose the Macri-sponsored soup kitchen, and zero otherwise. Propaganda is a dummy variable that equals 1 if the respondent was shown a part of an episode of 6, 7, 8, and zero otherwise. Age, Household Head, Years of Education, HH - Years of Education, Buenos Aires City, Greater Buenos Aires, Messi is Better, Poor Don't Make Effort and Penalty are included as controls. In column (1) Gender is also included as control. 